\title{
25. VELOCITY BEHAVIOR OF LOWER CRUSTAL AND UPPER MANTLE ROCKS FROM A FAST-SPREADING RIDGE AT HESS DEEP ${ }^{1}$
}

\author{
Gerardo J. Iturrino, ${ }^{2}$ D. Jay Miller, ${ }^{3}$ and Nikolas I. Christensen ${ }^{4}$
}

\begin{abstract}
Seismic velocities have been measured at confining pressures as high as $600 \mathrm{MPa}$ for lower crustal and upper mantle samples recovered during Ocean Drilling Program Leg 147. A comparison of porosity and density systematics with Southwest Indian Ridge Hole 735B and ophiolite data illustrates the more intense serpentinization of peridotites and more pervasive greenschist alteration characterizing the gabbros from Hess Deep. The degree of serpentinization and the olivine:orthopyroxene ratio of the Leg 147 samples control the density trends of the upper mantle rocks. The compressional- and shear-wave velocities show several types of seismic anisotropy caused by preferred mineral and microcrack orientations. Gabbroic samples are characterized by oriented plagioclase and olivine whereas the serpentinized peridotites show preferred horizontal microcrack orientation. Shear-wave splitting has been recorded and is attributed to preferred mineral orientation. The degree of serpentinization observed in the Hess Deep samples can be a significant factor in the reflectivity of the lower crust-upper mantle boundary. Gabbroic samples show lower Poisson's ratios than the highly serpentinized upper mantle rocks.
\end{abstract}

\section{INTRODUCTION}

Ocean Drilling Program (ODP) Leg 147 visited the Hess Deep area located in the deepest part of a westward-propagating oceanic rift valley that is opening up the eastern flank of the equatorial East Pacific Rise (EPR) and near the Cocos-Nazca-Pacific (CNP) plate triple junction (Fig. 1). Leg 147 drilled a total of thirteen holes coring approximately $518.3 \mathrm{~m}$ of basement and a thin sedimentary cover with a $23.9 \%$ recovery rate. Because of the complexity of the tectonic environment between the Galapagos microplate and the CNP triple junction (Lonsdale, 1988), the lower crustal and upper mantle sections recovered from these sites most likely represent sections that formed at either the Cocos-Galapagos or the Cocos-Nazca boundary. Since these sites are the first to drill into plutonic rocks at a fastspreading ridge, they should provide valuable information about the composition, evolution and structure of the lower oceanic crust and upper mantle as well as representing an excellent opportunity to measure the physical properties and test geophysical models of a relatively young crustal section.

Over the past several decades, the results of detailed bathymetric, petrologic, and geophysical surveys along mid-ocean ridges have caused early three layer models of the oceanic crust (Ewing and Ewing, 1959; Hess, 1962; Raitt, 1963; Le Pichon et al., 1965; Talwani et al., 1965; Shor et al., 1969) to be revised to a more detailed stratigraphic sequence influenced by variations in the frequency and viscosity of magma supply, spreading rate, and faulting mechanisms (Clauge and Bunch, 1976; Lewis and Garmany, 1982; Lonsdale, 1988; McCarthy et al., 1988; Sinton and Detrick, 1992). To test these new models it is important not only to determine the physical proper-

'Mével, C., Gillis, K.M., Allan, J.F., and Meyer, P.S. (Eds.), 1996. Proc. ODP, Sci Results, 147: College Station, TX (Ocean Drilling Program).

2Rosenstiel School of Marine and Atmospheric Sciences, Division of Marine Geology and Geophysics, Miami, FL 33149, U.S.A. iturrino@rcf.rsmds.miami.edu

${ }^{3}$ Ocean Drilling Program, Texas A\&M University Research Park, 1000 Discovery Drive, College Station, TX 77845-9547, U.S.A.

${ }^{4}$ Department of Earth and Atmospheric Sciences, Purdue University, West Lafayette, IN 47907 , U.S.A. ties of the upper basaltic layer but also to study continuous sequences from the deeper sections within the lower crust and upper mantle using deep drilling techniques. The physical properties and chemical compositions presented in this paper will provide the foundation for interpreting of the dynamic processes occurring at mid-ocean ridges which are responsible for the velocity and reflection structure of the uppermost rigid section of the oceanic lithosphere.

Seven holes were drilled at Site 894 with Hole $894 \mathrm{G}$ being the deepest with a total cored section of $154.5 \mathrm{~m}$ and a recovery rate of $35 \%$. Six holes were drilled at Site 895 with Holes 895D and 895E being the deepest, coring $93.7 \mathrm{~m}$ and $87.6 \mathrm{~m}$ with recovery rates of $21.4 \%$ and $37.1 \%$, respectively. Each section was divided into lithological units on the basis of primary igneous mineralogy, mineral compositions, deformation textures and structures. To investigate seismic anisotropy, both horizontal and vertical minicores were taken from the units that showed structures or mineral fabrics and that allowed such sampling. Samples were also taken at specific depths in order to cover the various textures and mineral assemblages recognized in the drill core. The locations of samples used for this study, the drilling history, recovery, and individual units for the three deepest holes are given in Figures 2 and 3.

\section{EXPERIMENTAL METHODS}

Mineralogical composition, crack porosity, bulk density, alteration, preferred mineral orientation, pore pressure, chemical composition, and temperature are the most important characteristics responsible for variations in seismic velocities throughout the oceanic crust. Because velocities at in-situ pressures are different from velocities at atmospheric pressure (Birch, 1960), it is important that velocity data used for crustal studies be obtained at elevated pressures and temperatures. In the following section the methods used for sample preparation as well as for density, porosity and velocity measurements are described in detail.

The drill core recovered during Leg 147 was cut along its axis on board the ship and horizontal as well as vertical minicores were drilled normal and parallel, respectively, to the drill core. The minicores had diameters that ranged from 1.25 to $2.5 \mathrm{~cm}$, depending upon 


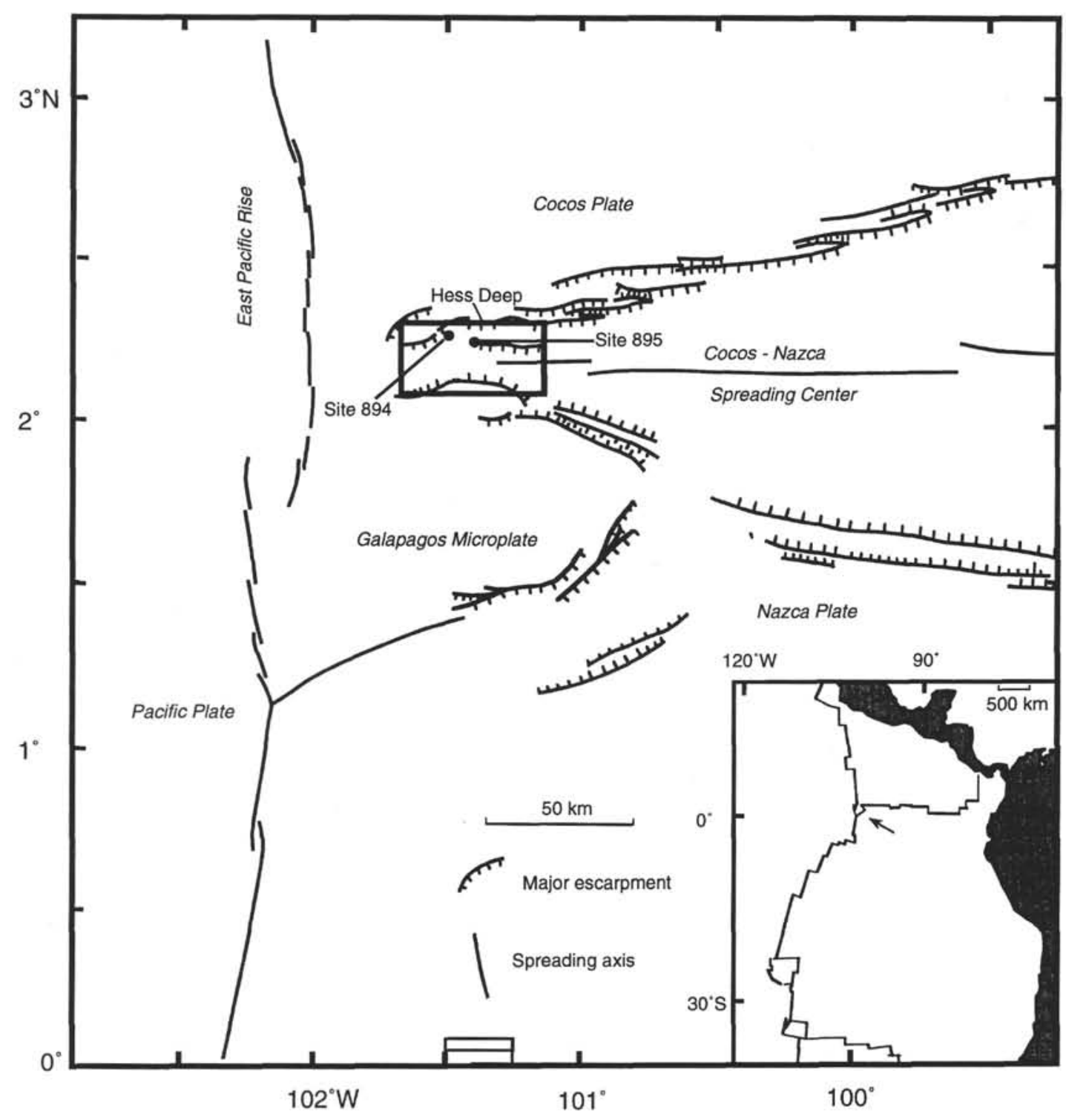

Figure 1. Map of the Hess Deep area within the plate configuration of the Pacific Ocean triple junction including the Pacific-Cocos-Nazca plates. Approximate locations of Sites 894 and 895 are also shown.

the grain size and varying lengths of 1.7 to $3.5 \mathrm{~cm}$. They were prepared with both ends flat and parallel to within $0.2 \mathrm{~mm}$ and thin sections were prepared from core ends billets. Compressional- and shear-wave velocities ( $\mathrm{Vp}$ and $\mathrm{Vs}$, respectively) were measured to confining pressures of $100 \mathrm{MPa}$ on all samples and to $600 \mathrm{MPa}$ on selected samples, using the pulse transmission method (Birch 1960; 1961); results are presented in Table 1.

All of the $100 \mathrm{MPa}$ velocity measurements were performed at the Petrophysics Laboratory of the Rosenstiel School of Marine and Atmospheric Science using a compound ultrasonic transducer system with a resonant frequency of $1 \mathrm{MHz}$. Velocity determinations are considered accurate to approximately $1 \%$ (Iturrino et al., 1995). This system is capable of simultaneously measuring Vp and Vs for two orthogonally polarized shear-waves as a function of confining pressure up to $100 \mathrm{MPa}$. All measurements were obtained at room temperature and a constant pore pressure of $2 \mathrm{MPa}$ to keep the samples saturated during the measurements while avoiding pore pressure build up. For most rock types, increasing temperature tends to decrease velocity by 2.0 to $6.0 \times 10^{-4} \mathrm{~km} / \mathrm{s}^{\circ} \mathrm{C}$ (Christensen, 1979). Hence, an error in esti- mation of $200^{\circ}$ in lower crustal temperature results in less than 0.1 $\mathrm{km} / \mathrm{s}$ error in seismic velocities for the relevant lithologies.

Using the pulse transmission method, several Vp and Vs measurements were also made at the Purdue University Rock Physics Laboratory at pressures up to $600 \mathrm{MPa}$ (Christensen 1965, 1985; Iturrino et al., 1991). As for the $100 \mathrm{MPa}$ measurements, the velocities were determined to an accuracy of $1 \%$ from the traveltime at room temperature of an elastic wave in a rock cylinder of known length using PZT and $\mathrm{AC}$ quartz transducers with resonant frequencies of $1 \mathrm{MHz}$. These particular measurements were obtained by sending simultaneous electronic pulses to a transducer on the sample and a transducer inside a calibrated mercury delay line. Both waveforms are displayed on a dual-trace oscilloscope, and the length of the mercury delay line is adjusted so that the signals can be superimposed, indicating that the pulse transmission time is the same for the sample and the mercury column. Sample velocity (v) is calculated from the measured sample length (1), the length of the mercury column $\left(\mathrm{l}_{\mathrm{Hg}_{\mathrm{g}}}\right)$, and the velocity of mercury $\left(\mathrm{V}_{\mathrm{Hg}}=1.446 \mathrm{~km} / \mathrm{s}\right.$ at $30^{\circ} \mathrm{C}$; Christensen, 1985$)$, according to the relationship 


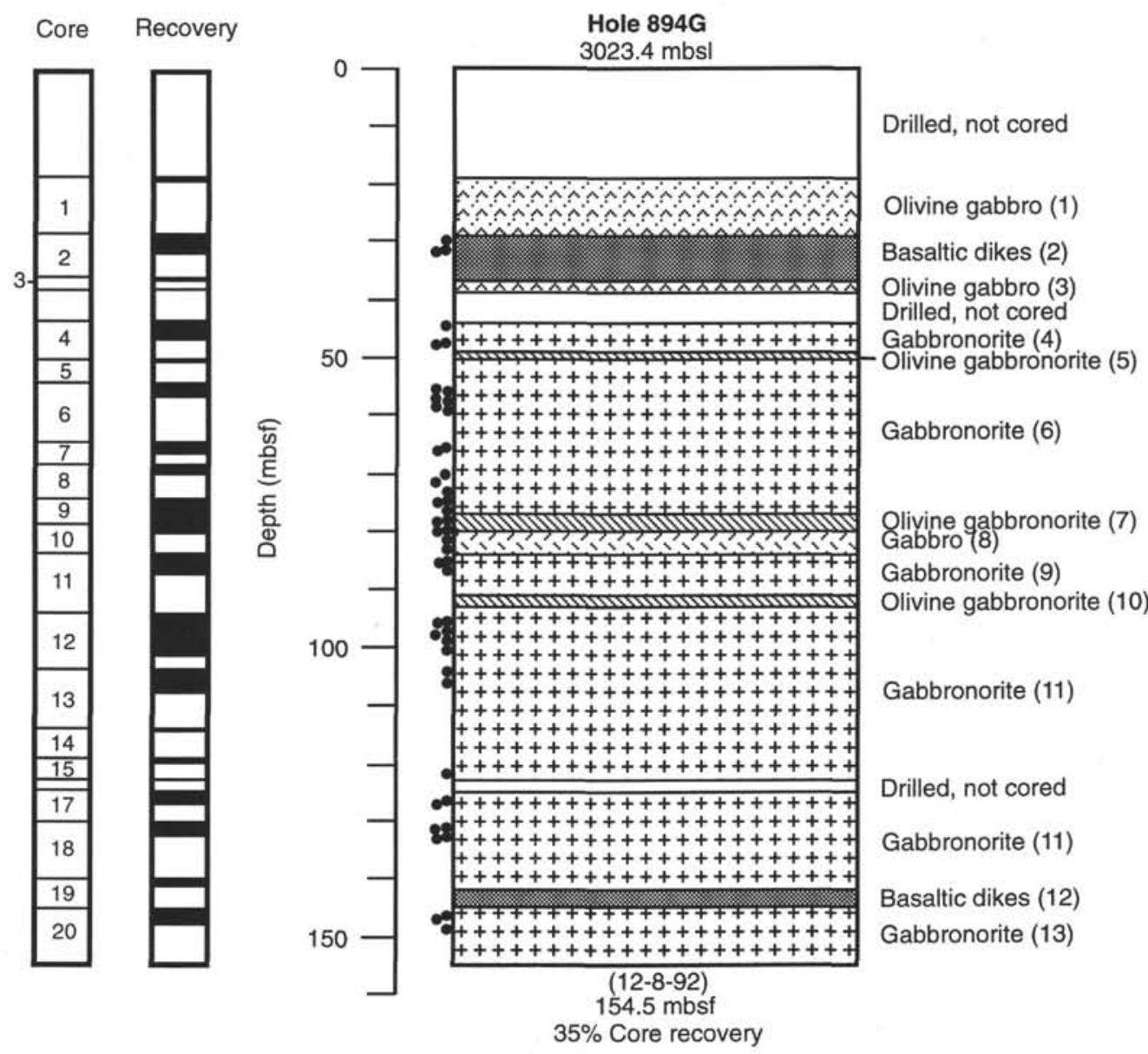

Figure 2. Drilling history, recovery, and lithostratigraphy of Hole 894G. Approximate sample locations are denoted by closed circles. Igneous unit numbers are given in parentheses.

$$
v=1 \mathrm{~V}_{\mathrm{Hg}} / \mathrm{I}_{\mathrm{Hg}} .
$$

Confining pressure was measured by monitoring the change in resistivity of a manganin coil in contact with the pressure medium.

The $600 \mathrm{MPa}$ velocity data was then plotted as a function of confining pressure as shown in Figure 4A. In principle, these curves can be used to extrapolate the $100 \mathrm{MPa}$ data to lower crustal and upper mantle pressures $(200 \mathrm{MPa})$ if it is assumed that similar rock types will behave similarly in the interval between 100 and $200 \mathrm{MPa}$. We also assume a linear relationship between the data collected at same interval. The second assumption is the most problematic because the most exaggerated curvature in the velocity-pressure profile (Fig. 4A) is in the interval below $200 \mathrm{MPa}$. For example, if we calculate the average change between the velocity measured at 100 and $200 \mathrm{MPa}$ for gabbroic rocks from Hess Deep, we obtain a value of $0.075 \mathrm{~km} / \mathrm{s} \pm$ $0.02 \mathrm{~km} / \mathrm{s}$, whereas for peridotites the average change is $0.092 \mathrm{~km} / \mathrm{s}$ $\pm 0.03 \mathrm{~km} / \mathrm{s}$. If these values are added to the $100 \mathrm{MPa}$ and then plot measured $200 \mathrm{MPa}$ data vs. predicted $200 \mathrm{MPa}$ data, a correlation coefficient of $\mathrm{R}^{2}>0.99$ is obtained (Fig. 4B). This correlation coefficient suggests that $200 \mathrm{MPa}$ values can be estimated accurately with this method.

Bulk density, porosity, and water content values were obtained by determining wet and dry sample weights and volumes using a motion-compensated microbalance for measuring mass $( \pm 0.002 \mathrm{~g}$ accuracy) and a pycnometer for measuring sample volumes $( \pm 0.03 \%)$. Volumes were obtained applying Archimedes' principle and using helium as a displacing fluid to assure helium penetration into crevices and pore spaces approaching one Angstrom $\left(10^{-10} \mathrm{~m}\right)$. Purge times of
$5 \mathrm{~min}$ were used to approach a helium-saturated steady-state condition. After measuring the wet weights, the samples were dried at $110^{\circ} \mathrm{C}$ for a period of $24 \mathrm{hr}$ to drive off water. The determination of water content followed the methods of the American Society for Testing and Materials (ASTM) designation D2216 (ASTM, 1989). As outlined in this procedure, corrections are required for salt when measuring marine samples. Samples were saturated in seawater and placed in a vacuum for $24 \mathrm{hr}$ to reproduce in-situ wet conditions. All measurements were corrected for salt assuming a pore water salinity of $35 \%$. This method was then used to calculate both bulk density and porosity values (Iturrino et al., 1995).

\section{RESULTS}

Porosity and density measurements as well as compressional- and shear-wave velocity measurements were performed on a 100 minicore samples. Lower crustal rocks from Hess Deep have a mean porosity value of $0.9 \%$ and a standard deviation of $1.19 \%$ whereas the mean bulk density for the gabbroic samples is $2.92 \mathrm{~g} / \mathrm{cm}^{3}$ with a standard deviation of $0.09 \mathrm{~g} / \mathrm{cm}^{3}$. The compressional-wave velocity mean value at $200 \mathrm{MPa}$ is $6.74 \mathrm{~km} / \mathrm{s}$ with a standard deviation of $0.45 \mathrm{~km} /$ $\mathrm{s}$ and the shear-wave velocity mean value at the same lower crustal pressures is $3.76 \mathrm{~km} / \mathrm{s}$ with a standard deviation of $0.26 \mathrm{~km} / \mathrm{s}$. The Hess Deep upper mantle samples have a mean porosity value of $2.64 \%$ and a standard deviation of $1.35 \%$ whereas the mean bulk density value is $2.63 \mathrm{~g} / \mathrm{cm}^{3}$ with a standard deviation of $0.10 \mathrm{~g} / \mathrm{cm}^{3}$. The $\mathrm{Vp}$ mean value at $200 \mathrm{MPa}$ is $5.46 \mathrm{~km} / \mathrm{s}$ with a standard deviation of 

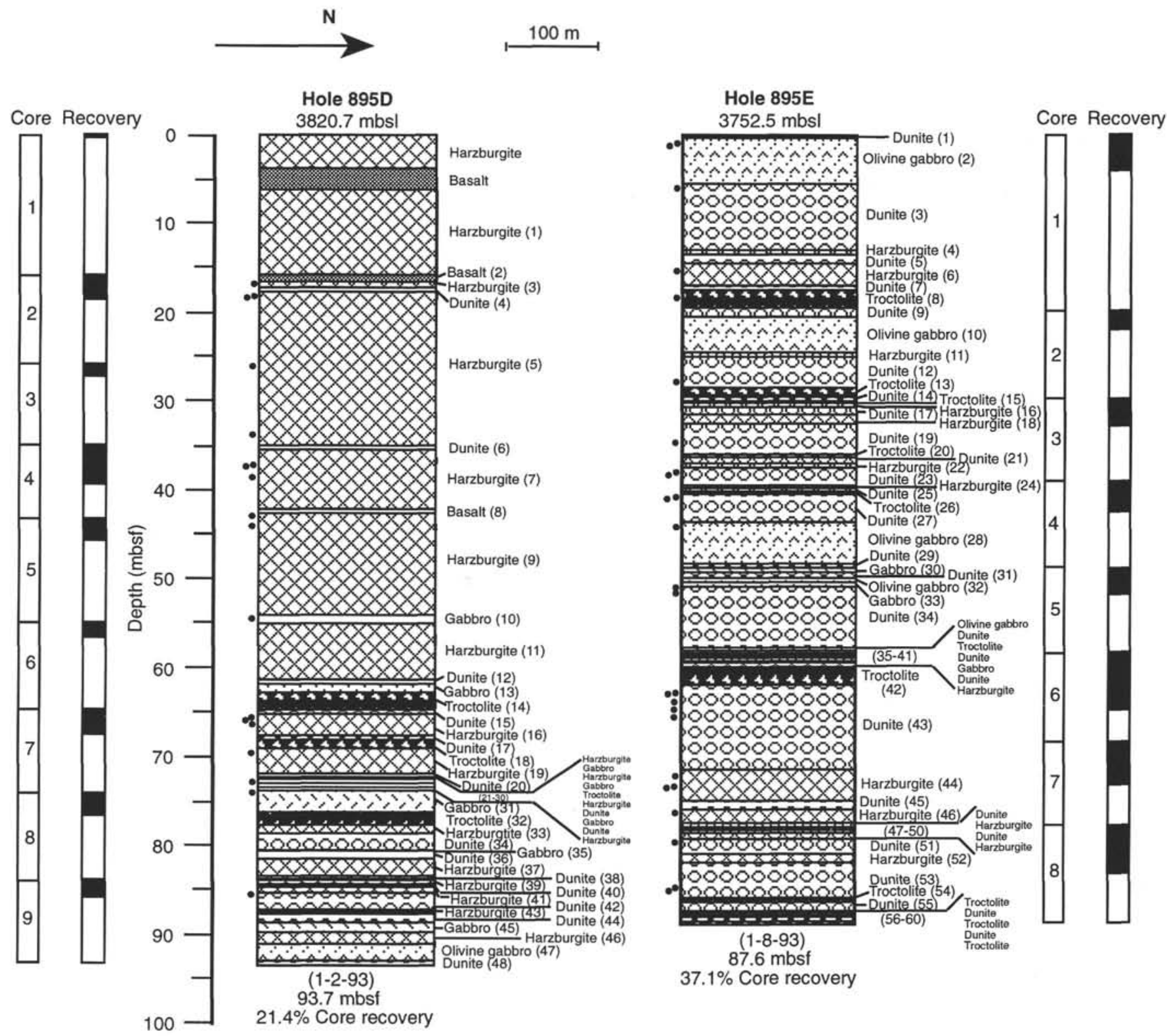

Figure 3. General drilling history, recovery, lithostratigraphy, and sample location for Holes 895D and 895E. Approximate sample locations are denoted by closed circles. Igneous unit numbers are given in parentheses.

$0.45 \mathrm{~km} / \mathrm{s}$ and the Vs mean value is $2.80 \mathrm{~km} / \mathrm{s}$ with a standard deviation of $0.30 \mathrm{~km} / \mathrm{s}$.

In the following discussions, the influence of porosity, density, alteration, mineralogical composition, and confining pressure on the seismic properties of the gabbroic rocks from Sites 894 and 895 are examined. Elastic constants calculated from measured laboratory velocities and densities are examined in detail as well as the elastic behavior of crustal rocks and their significance for future crustal drilling. Comparisons with ODP Hole $735 \mathrm{~B}$ and ophiolite data are also discussed.

\section{Porosity}

The effect of crack porosity on velocity behavior has been extensively studied in sedimentary, igneous and metamorphic rocks (Hyndman and Drury, 1976; Salisbury and Christensen, 1978; Christensen and Salisbury 1982; Schlumberger, 1989; Iturrino et al.,
1991). However, not until ODP Hole 735B, located on the Southwest Indian Ridge, were the in situ physical properties of gabbroic rocks from the oceanic crust studied in detail (Becker, 1991; Goldberg et al., 1991; Iturrino et al., 1991; Pezard et al., 1991). In the following section, the effects of crack porosity will be compared with data from the Southwest Indian Ridge and ophiolites.

A comparison of the density and porosity systematics for the Hess Deep gabbroic samples of Sites 894 and 895, Hole 735B (Iturrino et al., 1991) and Hole CY-4 in the Troodos ophiolite (Christensen and Salisbury, 1989) shows considerable variations (Fig. 5). The Leg 147 samples tend to have higher porosity values and lower densities than the less altered samples from Holes 735B and CY-4 (Fig. 5). In contrast, a significant number of the metagabbros found in the most altered and sheared zones of Hole 735B fall within the higher porosity and lower density trend displayed by the Hess Deep samples. These results suggest that in general, the gabbroic samples recovered during Leg 147 are more altered and fractured than Layer 3 samples from the 
Table 1. Index properties and variations in compressional- and shear-wave velocities as a function of confining pressure as well as propagation direction in water saturated samples, Leg 147.

\begin{tabular}{|c|c|c|c|c|c|c|c|c|c|c|c|c|c|c|c|}
\hline \multirow{2}{*}{$\begin{array}{l}\text { Core, section, } \\
\text { interval }(\mathrm{cm})\end{array}$} & Depth & Density & Porosity & & & & & Veloc & $(\mathrm{km} / \mathrm{s})$ & Pressut & $(\mathrm{MPa})$ & & & & \\
\hline & (mbsf) & $\left(\mathrm{kg} / \mathrm{m}^{3}\right)$ & $(\%)$ & Mode & 20 & 40 & 60 & 80 & 100 & 200 & 300 & 400 & 500 & 600 & Lithology \\
\hline $894 \mathrm{~F}-2 \mathrm{R}-1$ ( $(21-23)$ & 9.51 & 2.93 & 0.90 & $V_{p}$ & 6.25 & 6.36 & 6.43 & 6.47 & 6.51 & 6.61 & 6.68 & 6.72 & 6.75 & 6.78 & Gabbro \\
\hline & & & & vs & 3.34 & 3.52 & 3.61 & 3.65 & 3.68 & 3.72 & 3.73 & 3.74 & 3.75 & 3.76 & \\
\hline $894 \mathrm{G}-2 \mathrm{R}-1(109-115)$ & 29.70 & 2.90 & & $V_{p}$ & 6.41 & 6.45 & 6.48 & 6.50 & 6.51 & 6.55 & 6.57 & 6.59 & 6.61 & 6.75 & Basalt \\
\hline & & & & Vs & 3.51 & 3.52 & 3.52 & 3.53 & 3.53 & 3.54 & 3.55 & 3.55 & 3.55 & & \\
\hline $894 \mathrm{G}-2 \mathrm{R}-2(105-109) \mathrm{V}$ & 31.15 & 2.90 & 0.34 & $\begin{array}{l}\mathrm{Vp}_{\mathrm{p}} \\
\mathrm{Vs} 1\end{array}$ & 6.42 & $\begin{array}{l}6.44 \\
3.44\end{array}$ & $\begin{array}{l}6.47 \\
3.46\end{array}$ & $\begin{array}{l}6.50 \\
3.48\end{array}$ & $\begin{array}{l}6.53 \\
3.53\end{array}$ & & & & & & Basalt \\
\hline & & & & $\mathrm{V}_{\mathrm{s} 2}$ & & 3.43 & 3.45 & 3.50 & 3.57 & & & & & & \\
\hline $894 \mathrm{G}-2 \mathrm{R}-2(110-112)$ & 31.20 & 2.91 & 0.14 & $\mathrm{Vp}$ & 6.44 & 6.49 & 6.52 & 6.59 & 6.61 & & & & & & Basalt \\
\hline & & & & $\begin{array}{l}\text { Vs1 } \\
\text { Vs2 }\end{array}$ & $\begin{array}{l}3.56 \\
3.56\end{array}$ & $\begin{array}{l}3.59 \\
3.60\end{array}$ & $\begin{array}{l}3.60 \\
3.61\end{array}$ & $\begin{array}{l}3.61 \\
3.63\end{array}$ & $\begin{array}{l}3.64 \\
3.65\end{array}$ & & & & & & \\
\hline $894 \mathrm{G}-4 \mathrm{R}-1$ (9l-93) & 45.75 & 2.95 & & $V_{p}$ & 6.47 & 6.57 & 6.66 & 6.68 & 6.71 & 6.80 & 6.86 & 6.90 & 6.92 & 6.95 & Gabbronorite \\
\hline & & & & Vs & 3.47 & 3.61 & $\begin{array}{l}3.60 \\
3.69\end{array}$ & 3.73 & 3.75 & 3.79 & 3.82 & 3.83 & 3.84 & 3.85 & Jastivinte \\
\hline $894 \mathrm{G}-4 \mathrm{R}-2(71-75) \mathrm{V}$ & 47.05 & 2.91 & 0.57 & $\mathrm{~V}_{\mathrm{p}}$ & 6.48 & 6.50 & 6.53 & 6.57 & 6.61 & s.m & 5.02 & & & & Gabbronorite \\
\hline $894 \mathrm{G}-4 \mathrm{R}-2(76-78)$ & 47.10 & 2.88 & 0.39 & $v_{p}$ & 6.25 & 6.41 & 6.48 & 6.53 & 6.63 & & & & & & Gabbronorite \\
\hline $894 \mathrm{G}-6 \mathrm{R}-1(89-91)$ & 55.69 & 2.80 & 3.19 & $v_{p}$ & 5.77 & 5.86 & 5.92 & 6.09 & 6.20 & & & & & & Gabbronorite \\
\hline & & & & Vs1 & 2.82 & 2.92 & 2.99 & 3.11 & 3.28 & & & & & & \\
\hline 894G-6R-2 (78-80) & & & 0.23 & $\begin{array}{l}V_{s} 2 \\
V_{p}\end{array}$ & 2.79 & 3.03 & 3.05 & 3.09 & 3.23 & & & & & & \\
\hline $894 \mathrm{G}-6 \mathrm{R}-2(/ 8-80)$ & 57.01 & 3.03 & 0.23 & $\begin{array}{l}\mathrm{Vp} \\
\mathrm{Vs} 1\end{array}$ & $\begin{array}{l}6.87 \\
3.84\end{array}$ & $\begin{array}{l}6.91 \\
3.86\end{array}$ & $\begin{array}{l}6.95 \\
3.87\end{array}$ & $\begin{array}{l}6.99 \\
3.88\end{array}$ & $\begin{array}{r}7.04 \\
3.90\end{array}$ & & & & & & Gabbronorite \\
\hline & & & & Vs2 & 3.80 & $\begin{array}{l}3.00 \\
3.82\end{array}$ & $\begin{array}{l}3.87 \\
3.84\end{array}$ & $\begin{array}{l}3.80 \\
3.86\end{array}$ & 3.87 & & & & & & \\
\hline 894G-7R-1 (43-45) & 65.13 & 2.97 & 0.91 & $\mathrm{~V}_{\mathrm{p}}$ & 6.44 & 6.53 & 6.58 & 6.61 & 6.63 & 6.71 & 6.76 & 6.80 & 6.83 & 6.86 & Gabbronorite \\
\hline & & & & Vs & 3.61 & 3.68 & 3.72 & 3.75 & 3.76 & 3.79 & 3.80 & 3.81 & 3.82 & 3.82 & \\
\hline $894 \mathrm{G}-7 \mathrm{R}-2(6-8)$ & 66.26 & 2.96 & 0.45 & $V_{p}$ & 6.63 & 6.69 & 6.73 & 6.77 & 6.82 & & & & & & Gabbronorite \\
\hline $894 \mathrm{G}-8 \mathrm{R}-1$ (54-56) & 69.04 & 2.73 & 6.57 & $\mathrm{vp}_{\mathrm{p}}$ & 5.62 & 5.68 & 5.71 & 5.80 & 5.86 & & & & & & Gabbronorite \\
\hline & & & & $\begin{array}{l}\text { Vs1 } \\
\text { Vs2 }\end{array}$ & & & & $\begin{array}{l}3.09 \\
3.12\end{array}$ & 3.10 & & & & & & \\
\hline $894 \mathrm{G}-8 \mathrm{R}-2(3 \mathrm{I}-33)$ & 70.31 & 2.94 & 0.78 & $\begin{array}{l}V_{s 2} \\
V_{p}\end{array}$ & 6.45 & 6.49 & 6.53 & $\begin{array}{l}3.12 \\
6.57\end{array}$ & $\begin{array}{l}3.16 \\
6.61\end{array}$ & & & & & & Gabbronorite \\
\hline $894 \mathrm{G}-8 \mathrm{R}-2(107-109)$ & 71.07 & 2.98 & 0.31 & $v_{p}$ & 6.65 & 6.74 & 6.79 & 6.82 & 6.85 & 6.92 & 6.97 & 7.00 & 7.03 & 7.06 & Gabbronorite \\
\hline & & & & Vs & 3.53 & 3.72 & 3.79 & 3.81 & 3.82 & 3.84 & 3.85 & 3.86 & 3.86 & 3.86 & \\
\hline 894G-9R-1 (37-39) & 74.77 & 2.95 & 0.63 & $\mathrm{Vp}$ & 6.53 & 6.61 & 6.66 & 6.70 & 6.72 & 6.81 & 6.87 & 6.91 & 6.94 & 6.97 & Gabbronorite \\
\hline & & & & Vs & 3.49 & 3.64 & 3.71 & 3.75 & 3.77 & 3.82 & 3.85 & 3.87 & 3.89 & 3.90 & \\
\hline 894G-9R-3 (69-71) & 78.09 & 2.96 & 1.17 & $v_{p}$ & 5.94 & 6.14 & 6.19 & 6.28 & 6.36 & & & & & & Gabbronorite \\
\hline 894G-9R-4 (54-59) & 79.44 & 2.97 & & $\mathrm{Vp}_{\mathrm{p}}$ & 6.84 & 6.89 & 6.91 & 6.93 & 6.94 & 6.98 & 7.01 & 7.03 & 7.05 & 7.07 & Gabbronorite \\
\hline & & & & Vs & 3.87 & 3.88 & 3.89 & 3.89 & 3.90 & 3.92 & 3.93 & 3.93 & 3.94 & 3.95 & 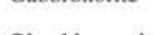 \\
\hline $894 G-9 R-4(123-127) \mathrm{V}$ & 80.13 & 2.98 & 0.09 & Vp & 7.06 & 7.08 & 7.11 & 7.14 & 7.16 & & & & & & Ol gabbronorite \\
\hline & & & & Vs1 & 3.83 & 3.84 & 3.79 & 3.88 & 3.90 & & & & & & \\
\hline & & & & Vs2 & 3.76 & 3.79 & 3.80 & 3.88 & 3.90 & & & & & & \\
\hline 894G-9R-4 (130-132) & 80.20 & 2.98 & 0.09 & $v_{p}$ & 6.95 & 7.10 & 7.20 & 7.25 & 7.31 & & & & & & Ol gabbronorite \\
\hline & & & & Vs1 & 3.80 & 3.96 & 3.97 & 4.02 & 4.14 & & & & & & \\
\hline $894 \mathrm{G}-10 \mathrm{R}-1$ (81-83) & 81.36 & 3.01 & 0.24 & Vs2 & 3.71 & 3.81 & 3.84 & 3.91 & 3.99 & & & & & & \\
\hline & 81.36 & & & $V_{p}$ & 6.91 & $\begin{array}{l}6.95 \\
3.57\end{array}$ & 6.99 & 7.06 & 7.10 & & & & & & Gabbro \\
\hline $894 \mathrm{G}-10 \mathrm{R}-2(38-40)$ & 82.43 & 3.01 & 0.16 & $v_{p}$ & $\begin{array}{l}3.53 \\
6.76\end{array}$ & $\begin{array}{l}3.57 \\
6.82\end{array}$ & $\begin{array}{l}3.61 \\
6.86\end{array}$ & $\begin{array}{l}3.67 \\
6.89\end{array}$ & $\begin{array}{l}3.70 \\
6.92\end{array}$ & 6.98 & 7.02 & 7.05 & 7.08 & 7.09 & Gabbronorite \\
\hline & & & 0.10 & $\mathrm{~V}_{\mathrm{s}}^{\mathrm{p}}$ & 3.72 & 3.80 & 3.85 & 3.87 & 3.89 & 3.93 & 3.95 & 3.96 & 3.97 & 3.98 & \\
\hline 894G-11R-1 (135-137) & 85.45 & 2.90 & 0.68 & $v_{p}$ & 6.32 & 6.41 & 6.46 & 6.49 & 6.52 & 6.59 & 6.64 & 6.67 & 6.69 & 6.71 & Gabbronorite \\
\hline $\left.894 G_{-}-1\right)-2(45-47)$ & 8605 & 285 & 293 & $V_{s}^{\prime}$ & $\begin{array}{l}3.52 \\
5.89\end{array}$ & $\begin{array}{l}3.62 \\
5.05\end{array}$ & 3.67 & 3.70 & 3.71 & 3.74 & 3.75 & 3.76 & 3.76 & 3.77 & \\
\hline $894 G-11 R-2(45-47)$ & 86.05 & 2.85 & 2.93 & $\begin{array}{l}V_{p} \\
V_{s 1}\end{array}$ & $\begin{array}{r}3.89 \\
3.06\end{array}$ & $\begin{array}{l}5.95 \\
3.09\end{array}$ & $\begin{array}{l}6.00 \\
3.11\end{array}$ & $\begin{array}{l}6.06 \\
3.13\end{array}$ & 6.11 & & & & & & Gabbronorite \\
\hline & & & & $\begin{array}{l}\text { Vs1 } \\
\text { Vs2 }\end{array}$ & $\begin{array}{l}3.00 \\
3.07\end{array}$ & $\begin{array}{l}3.09 \\
3.11\end{array}$ & $\begin{array}{l}3.11 \\
3.17\end{array}$ & $\begin{array}{l}3.13 \\
3.24\end{array}$ & $\begin{array}{l}3.15 \\
3.26\end{array}$ & & & & & & \\
\hline $894 \mathrm{G}-12 \mathrm{R}-2(46-50) \mathrm{V}$ & 95.76 & 2.86 & 0.55 & $\mathrm{~V}_{\mathrm{p}}$ & 6.53 & 6.58 & 6.60 & 6.66 & 6.68 & & & & & & Gabbronorite \\
\hline & & & & $\begin{array}{l}\text { Vs1 } \\
\text { Vs2 }\end{array}$ & & & & $\begin{array}{l}3.40 \\
3.41\end{array}$ & 3.41 & & & & & & \\
\hline $894 \mathrm{G}-12 \mathrm{R}-2(50-52)$ & 95.80 & 2.91 & 1.35 & $v_{p}$ & 6.63 & 6.67 & 6.73 & $\begin{array}{l}3.41 \\
6.81\end{array}$ & $\begin{array}{l}3.42 \\
6.87\end{array}$ & & & & & & Gabbronorite \\
\hline & & & & Vs1 & & & 3.42 & 3.50 & 3.54 & & & & & & \\
\hline & & & & Vs2 & 3.14 & 3.23 & 3.36 & 3.49 & 3.54 & & & & & & \\
\hline 894G-12R-3 (147-149) & 98.27 & 3.00 & 0.38 & $V_{p}$ & 6.69 & 6.75 & 6.80 & 6.8 & 6.93 & & & & & & Gabbronorite \\
\hline $894 G-12 R-4(51-53)$ & 98.81 & 3,00 & 0.38 & $V_{p}$ & 6.77 & 6.83 & 6.88 & $\begin{array}{l}6.96 \\
3.64\end{array}$ & 7.01 & & & & & & Gabbronorite \\
\hline $894 \mathrm{G}-12 \mathrm{R}-5(79-81)$ & 100.59 & 2.99 & 0.34 & $\begin{array}{l}\text { Vs2 } \\
\text { Vpp }\end{array}$ & 6.75 & 6.79 & 6.86 & $\begin{array}{l}3.6 \\
6.9\end{array}$ & $\begin{array}{l}3.71 \\
6.96\end{array}$ & & & & & & Gabbronorite \\
\hline $894 \mathrm{G}-12 \mathrm{R}-5(108-112)$ & 100.88 & 2.93 & & $v_{p}$ & 6.71 & 6.77 & 6.8 & 6.8 & 6.86 & 6.92 & 6.96 & 6.98 & 7.00 & 7.02 & Gabbronorite \\
\hline & & & & Vs & 3.70 & 3.78 & 3.8 & 3.8 & 3.8 & 3.90 & 3.91 & 3.9 & 3.93 & 3.93 & \\
\hline $894 \mathrm{G}-12 \mathrm{R}-6$ (43-48) & 101.73 & 2.97 & & $V_{p}$ & 6.66 & 6.72 & 6.7 & 6.7 & 6.8 & 6.87 & 6.91 & 6.9 & 6.96 & 6.98 & Gabbronorite \\
\hline & & & & Vs & 3.7 & 3.75 & 3.7 & 3.8 & 3.8 & 3.8 & 3.8 & 3. & 3. & 3.87 & \\
\hline $894 \mathrm{G}-13 \mathrm{R}-1(86-89)$ & 104.26 & 3.04 & & $V_{p}$ & 6.7 & 6.8 & 6. & & 6. & 7.00 & 7.05 & 7.0 & 7. & 7.12 & Gabbronorite \\
\hline & & & & Vs & 3.83 & 3.87 & 3.9 & 3.9 & 3.93 & 3.97 & 3.99 & 4.0 & 4. & 4.01 & \\
\hline 894G-13R-1 (89-91) & 104.29 & 3.02 & 0.35 & $V_{p}$ & 6.67 & 6.77 & 6.8 & 6.8 & 6.89 & 6.97 & 7.02 & 7.05 & 7.6 & 7.10 & Gabbronorite \\
\hline & & & & Vs & 3.69 & 3.81 & 3.87 & 3.90 & 3.92 & 3.96 & 3.97 & 3.98 & 3.99 & 3.93 & \\
\hline $894 G-13 R-3(5-7)$ & 104.45 & 3.04 & 0.84 & $v_{p}$ & 6.55 & 6.61 & 6.65 & 6.71 & 6.75 & & & & & & Gabbronorite \\
\hline $894 \mathrm{G}-16 \mathrm{~W}-1(43-45)$ & 123.23 & 2.97 & 0.91 & $\begin{array}{l}V_{p} \\
V_{s 1}\end{array}$ & $\begin{array}{l}6.70 \\
3.44\end{array}$ & $\begin{array}{l}6.76 \\
3.48\end{array}$ & $\begin{array}{l}6.81 \\
3.52\end{array}$ & 6.87 & $\begin{array}{l}6.91 \\
3.61\end{array}$ & & & & & & Gabbronorite \\
\hline & & & & $\begin{array}{l}\text { Vs1 } \\
\text { Vs2 }\end{array}$ & $\begin{array}{l}3.44 \\
3.42\end{array}$ & 3.48 & 3.5 & $\begin{array}{l}3.5 \\
3 .\end{array}$ & $\begin{array}{l}3.61 \\
3.63\end{array}$ & & & & & & \\
\hline 894G-17R-2 (7-9) & 127.37 & 3.04 & 0.25 & $\mathrm{Vp}$ & 6.94 & 6.99 & 7.6 & 7. & 7.12 & & & & & & Gabbronorite \\
\hline & & & & Vs1 & 3.6 & 3.6 & 3.7 & 3.7 & 3.77 & & & & & & \\
\hline & & & & Vs2 & & 3.6 & 3. & & 3.7 & & & & & & \\
\hline $894 \mathrm{G}-17 \mathrm{R}-2(87-89)$ & 128.17 & 2.96 & & $V_{p}$ & 6.71 & 6.79 & 6.83 & 6.8 & 6.89 & 6.95 & 6.99 & 7.01 & 7.03 & 7.04 & Gabbronorite \\
\hline & & & & Vs & 3.79 & 3.83 & 3.86 & 3.88 & 3.90 & 3.93 & 3.95 & 3.97 & 3.97 & 3.98 & \\
\hline $894 \mathrm{G}-18 \mathrm{R}-1$ (69-71) & 131.59 & 3.00 & 0.41 & $V_{p}$ & 6.79 & 6.86 & 6.90 & 6.94 & 6.98 & & & & & & Gabbronorite \\
\hline & & & & Vs1 & 3.4 & 3. & 3. & & 3.6 & & & & & & \\
\hline & & & & Vs2 & 3.5 & 3.5 & 3. & 3. & 3.68 & & & & & & \\
\hline $894 \mathrm{G}-18 \mathrm{R}-1(72-76) \mathrm{V}$ & 131.62 & 2.89 & 0.26 & $\mathrm{Vp}_{\mathrm{p}}$ & 6.71 & 6.74 & 6.77 & 6.8 & 6.83 & & & & & & Gabbronorite \\
\hline & & & & Vs1 & 3.22 & 3.25 & 3.27 & 3.30 & 3.34 & & & & & & \\
\hline & & & & $V_{s} 2$ & 3.25 & 3.28 & 3.30 & 3.31 & 3.32 & & & & & & \\
\hline 894G-18R-1 (130-132) & 132.20 & 3.01 & 0.74 & $\mathrm{Vp}$ & 6.58 & 6.68 & 6.74 & 6.77 & 6.80 & 6.87 & 6.91 & 6.94 & 6.96 & & Olivine gabbro \\
\hline $894 G_{-1}=8 R-2(94-96$ & 133.34 & & & Vss & 3.51 & 3.64 & 3.71 & 3.74 & 3.76 & 3.80 & 3.81 & 3.82 & 3.82 & 3.83 & \\
\hline 894G-18R-2 (94-96) & 133.34 & 2.81 & 1.33 & $\begin{array}{l}V_{p} \\
V_{s 1}\end{array}$ & 5.77 & 5.84 & $\begin{array}{l}5.89 \\
2.87\end{array}$ & $\begin{array}{l}5.94 \\
2.99\end{array}$ & $\begin{array}{l}6.00 \\
3.07\end{array}$ & & & & & & $\begin{array}{l}\text { Cataclastic } \\
\text { gabbro }\end{array}$ \\
\hline & & & & Vs2 & & & 2.95 & 3.10 & 3.14 & & & & & & \\
\hline
\end{tabular}


Table 1 (continued).

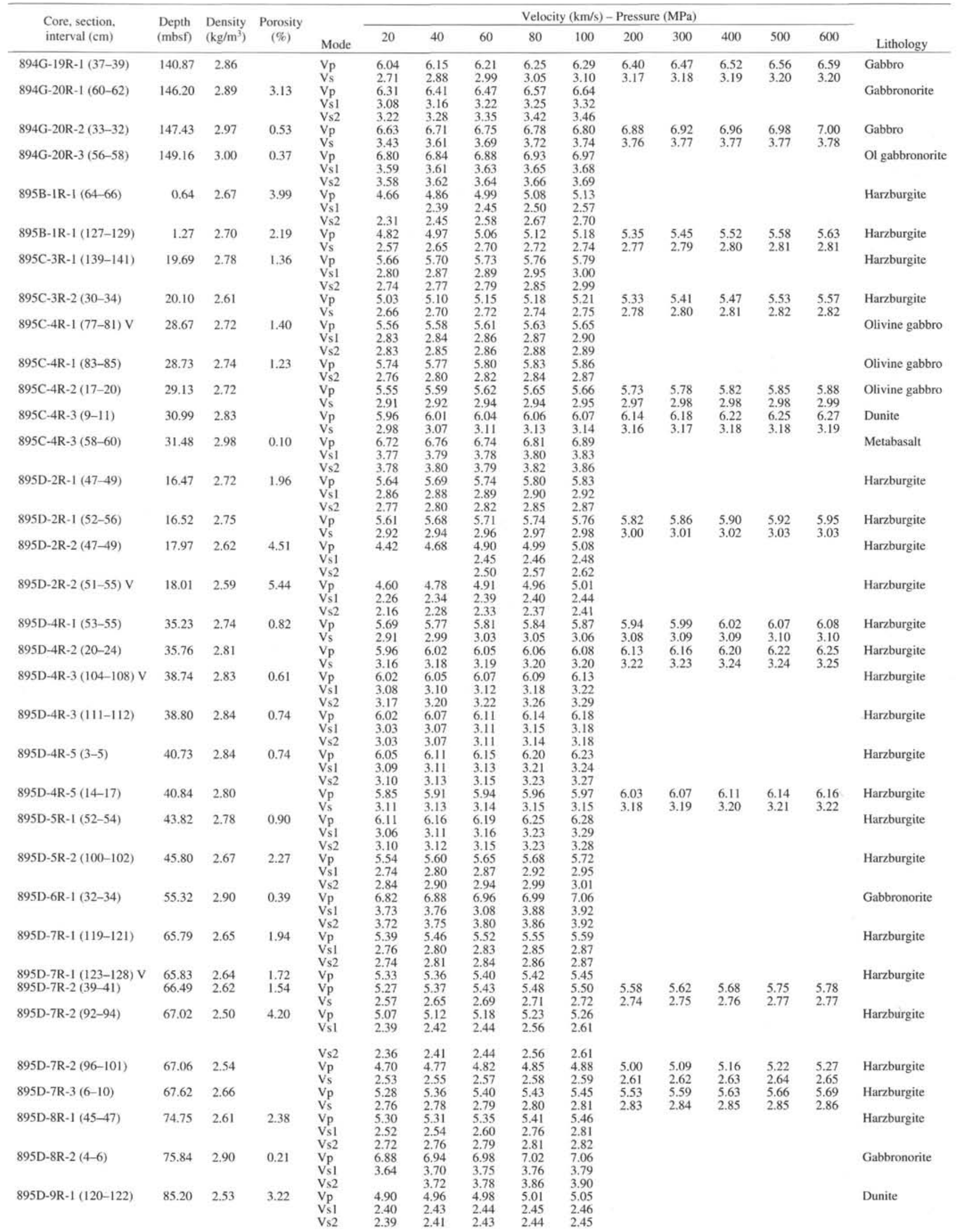


Table 1 (continued).

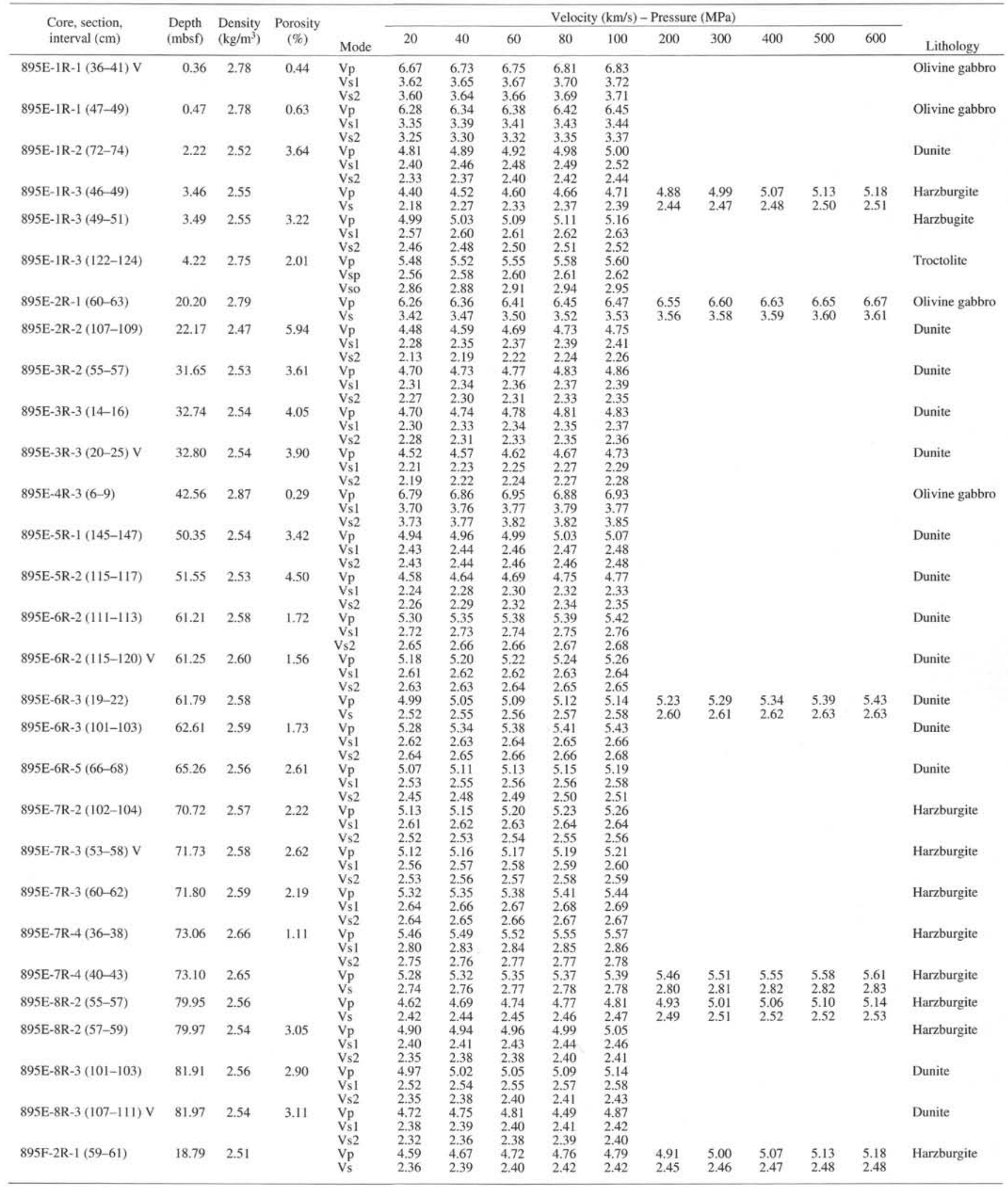

Notes: $\mathrm{V}=$ vertical sample; $\mathrm{ol}=$ olivine, $\mathrm{Vp}=$ compressional-wave velocity; for horizontal samples: $\mathrm{V} s 1=$ shear-wave vibrating vertically, $\mathrm{Vs} 2=$ shear-wave vibrating horizontally, $V_{s p}=$ shear-wave vibrating parallel to foliation, Vso = shear-wave vibrating orthogonally to foliation, Vs = shear-wave in no particular orientation; vertical samples Vs1 and Vs2 vibrate perpendicular to each other in the horizontal plane. 


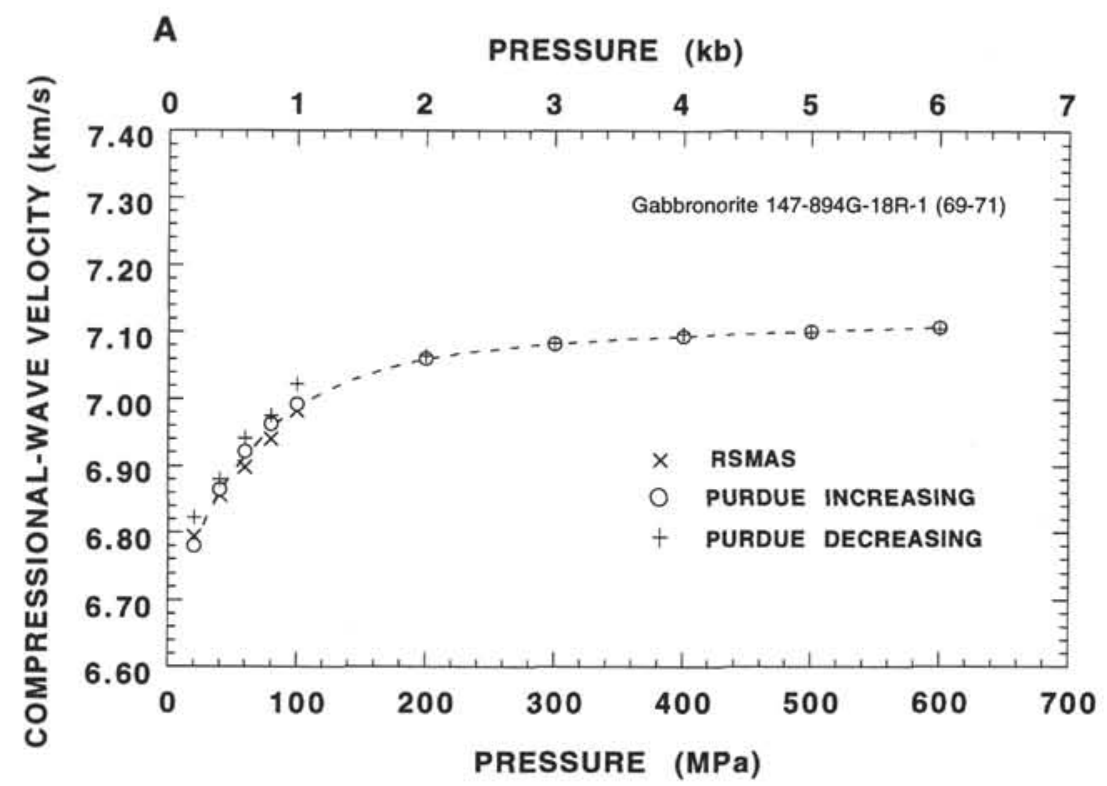

B

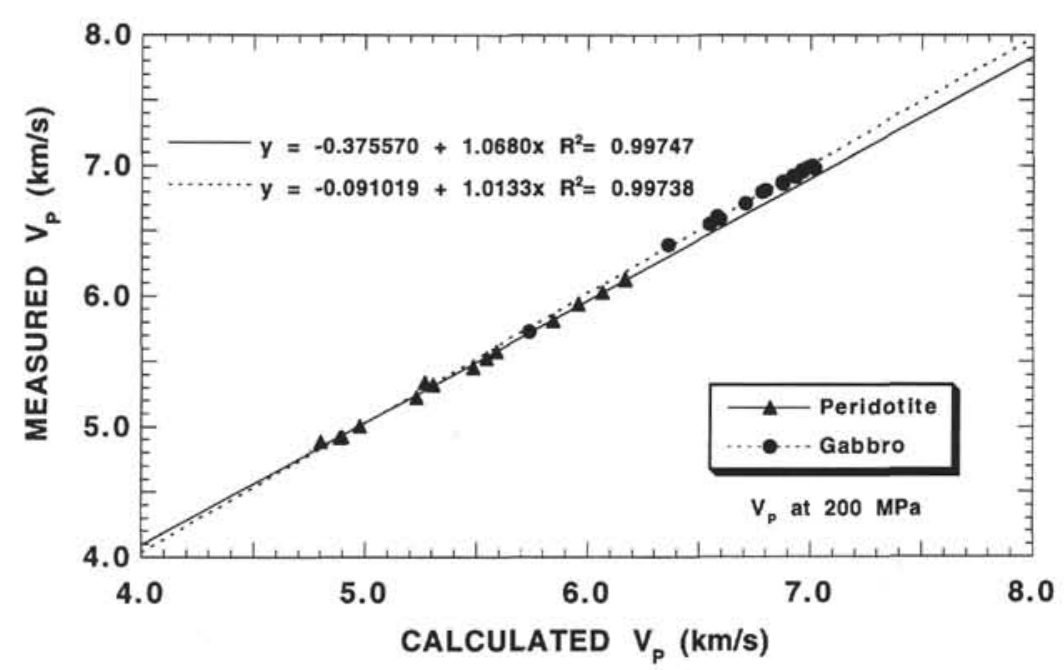

Figure 4. A. Compressional-wave velocity relationship as a function of increasing confining pressure. B. Linear relationship between velocities measured at $200 \mathrm{MPa}$ and $200 \mathrm{MPa}$ values calculated for the same samples using the values obtained from curves such as shown in Figure $4 \mathrm{~A}$.

other two localities. The olivine gabbros and gabbroic samples from Holes $735 \mathrm{~B}$ and CY-4 display low porosity values for a significant range in densities ( 2.85 to $\left.3.15 \mathrm{~g} / \mathrm{cm}^{3}\right)$. This range in density can be attributed to variations in primary igneous mineral phases with a small degree of alteration. Low porosity values are likely to be due to infilling of pre-existing cracks by alteration products and, in the case of Hole CY-4, the overburden pressure caused by the overlying sheeted dikes which would close most of the original porosity.

The complex tectonic history of exhumation and emplacement of lower crustal rocks represented in the lithostratigraphic sequences penetrated at Sites 894 and 895 presumably resulted in fracturing and consequently, to the alteration of the gabbroic section. The continuous tectonic influence of the nearby triple junction has perhaps allowed some of the cracks to continuously propagate and prevented complete microcrack closure and the total infilling of alteration products. This conclusion is supported by the presence of 27 open fractures identified within the Hole $894 \mathrm{G}$ core (Gillis, Mével, Allan, et al., 1993). Thin-section analyses in conjunction with core observa- tions have also recorded several tectonic episodes by recognizing the presence of macroscopic veins crosscutting and therefore postdating several generations of microscopic veinlets (Gillis, Mével, Allan et al., 1993).

The upper mantle peridotites recovered from Site 895 show markedly different density-porosity systematics. There is a distinct linear trend defined by the data from serpentinized dunite samples (Fig. 6), in which density is observed to decrease slowly with increasing porosity. While porosity is a fairly straightforward parameter, several factors can influence the density of mineral aggregates. These include (1) mineralogical composition (i.e., olivine density ranges from $3.2 \mathrm{~g} / \mathrm{cm}^{3}$ to $4.4 \mathrm{~g} / \mathrm{cm}^{3}$ depending on the forsterite to fayalite ratio), (2) phase contributions and degree of alteration of those phases (i.e., ratio of olivine to orthopyroxene to serpentine), and (3) porosity. The serpentinized dunites from Hess Deep are effectively monomineralic, have a constant composition, and are all pervasively altered (Gillis, Mével, Allan, et al., 1993). A narrow range in grain density from 2.56 $\mathrm{g} / \mathrm{cm}^{3}$ to $2.64 \mathrm{~g} / \mathrm{cm}^{3}$, a mean of $2.60 \mathrm{~g} / \mathrm{cm}^{3}$, and a low standard devi- 


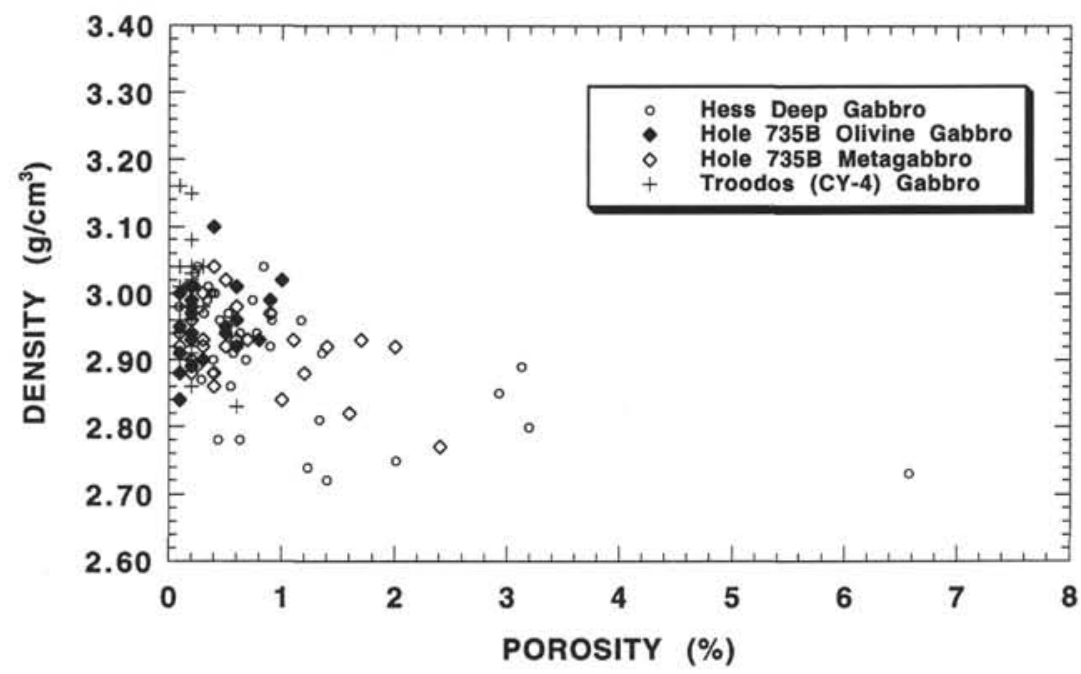

Figure 5. Comparison of the density-porosity relationship of the gabbroic rocks obtained from Leg 147 with similar samples from ODP Hole 735B on the Southwest Indian Ridge and Hole CY-4 in the Troodos ophiolite.

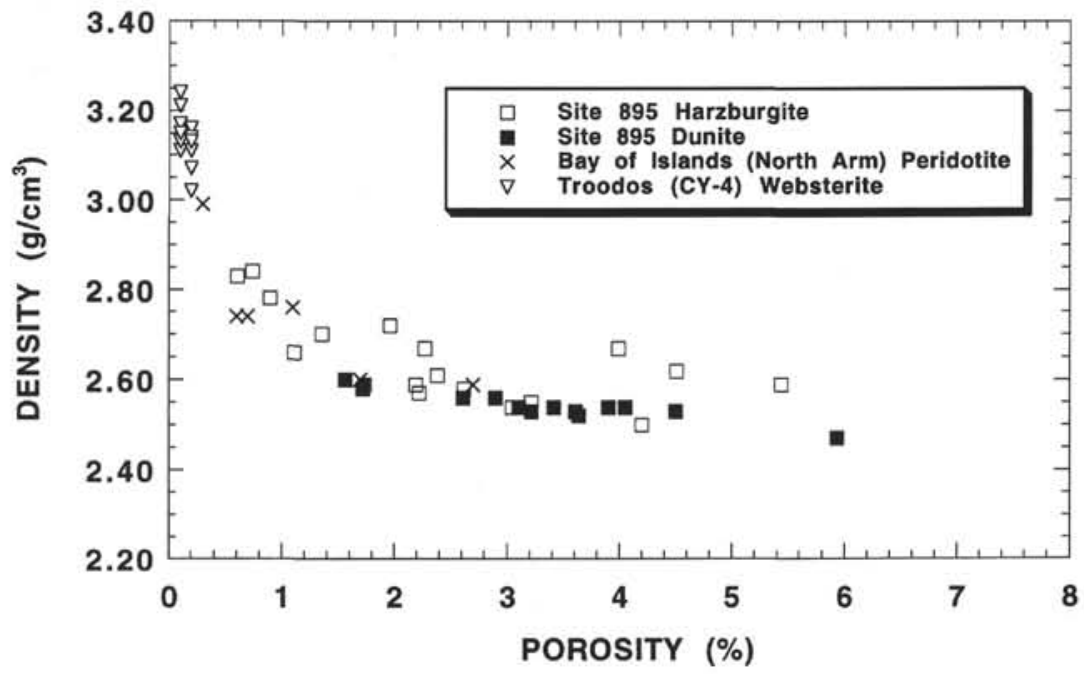

Figure 6. Density-porosity relationship for upper mantle rocks from Site 895, the Bay of Islands North Arm massif, and Hole CY-4 in the Troodos ophiolite. A linear fit has been applied only to the dunite data from Site 895 in order to show the trend.

ation of $\pm 0.02 \mathrm{~g} / \mathrm{cm}^{3}$ for 21 dunite samples implies very small compositional variations. Therefore, the only factor contributing to the variability in serpentinized dunite density must be microcrack porosity. Analyses of the serpentinized dunites from Site 895 appears to show a $0.03 \mathrm{~g} / \mathrm{cm}^{3}$ decrease in density for each $1 \%$ increase in porosity. This value precisely agrees with the expected change in density due solely to volumetric expansion of a massive serpentinite with progressively increasing pore space.

The measured values from harzburgite data collected at Hess Deep cannot be so simply explained. The mean grain density for 17 harzburgite samples is $2.72 \mathrm{~g} / \mathrm{cm}^{3}$ with a standard deviation of \pm 0.09 $\mathrm{g} / \mathrm{cm}^{3}$ and a range from $2.57 \mathrm{~g} / \mathrm{cm}^{3}$ to $2.87 \mathrm{~g} / \mathrm{cm}^{3}$. In this case, the significantly higher scatter and non-linearity in the data implies that density do not depend solely on microcrack porosity (Fig. 6). Considering again the contributions of various factors to the density of mineral aggregates besides volumetric expansion due to porosity, two components appear to be controlling density behavior in these rocks. Since the chemical composition of olivine and pyroxene in these samples do not vary enough to make a significant contribution to the density (Miller et al., this volume), and neither does the composition of serpentine (Gillis, Mével, Allan, et al., 1993), only the proportions of these phases and/or the degree of serpentinization must be the primary control on the density variability. Isolation of the relative contribution of these two parameters to density awaits detailed image analysis of mineralogical components.

Inasmuch as these serpentinized peridotites represent upper mantle lithologies, we can develop contrasts with data sets from other terranes interpreted to have been derived from the upper mantle. Websterites from the Troodos ophiolite and serpentinized peridotite from the North Arm ophiolite in the Bay of Islands generally exhibit lower porosity and higher density than any rock recovered from Hess Deep (Fig. 6). Troodos websterites are characterized by rare pockets of olivine enrichment with a small degree of localized serpentinization (Thy et al., 1989) whereas all the peridotite samples from the Bay of Islands and Hess Deep have a significantly more olivine and are more or less pervasively serpentinized. Since fracture density controls the processes of hydration and serpentinization, the density of the these upper mantle rocks must be closely related to the fracture porosity. Even though the origin of websterites is still under debate, the slightly less dense Troodos samples fall in a region close to where fresh low porosity peridotites would plot (Fig. 6). Hence, the websterite data set may represent the low porosity end member for upper mantle rocks. 
The density-porosity relationship for the complete data set of ultramafic rocks presented here seems to behave exponentially with the inflection point at a porosity of approximately 1\% (Fig. 6). However, a more complete analysis of the data is necessary to determine any empirical relationship.

\section{Density and Alteration}

A comparison between compressional-wave velocity, density and mean atomic weight for the Hess Deep, Hole 735B (Iturrino et al., 1991) and ophiolite (Christensen and Salisbury, 1982; 1989; Christensen and Smewing, 1981; Salisbury and Christensen, 1978) lower crustal samples shows a clustering of points around a mean $\mathrm{Vp}=7.10$ $\mathrm{km} / \mathrm{s}$, a mean density of $2.95 \mathrm{~g} / \mathrm{cm}^{3}$, and a mean atomic weight (MAW) of 21 (Fig. 7A). A pressure of $200 \mathrm{MPa}$ was chosen for the analyses because this value closely approximates in-situ conditions for the lower oceanic crust. The lines of constant mean atomic weight were obtained using Birch's Law (Birch, 1960; 1961) corrected for $200 \mathrm{MPa}$ values (Iturrino et al., 1991).

Iron free silicates have mean atomic weights near 20 and the mean atomic weight for common rocks is 21 (Birch, 1961). The most common elements that produce deviations from a MAW of 20 are calcium, iron, and titanium. Most of the olivine gabbro, hornblende gabbro, and pyroxene gabbro samples from ophiolites and Hole $735 \mathrm{~B}$ used for these analyses were relatively fresh and fall in a cluster close to a mean atomic weight of 21 . In contrast, the majority of the rocks from Hess Deep have a lower density and many samples have a mean atomic weight of greater than 21 (Table 2 and Fig. 7A). High mean atomic weight in the Hess Deep gabbroic rocks is result of abundant Fe-bearing hydrous phases (i.e., amphibole and epidote), products of greenschist facies metamorphism (Gillis, Mével, Allan, et al., 1993). The peridotites from Hess Deep also exhibit a deviation from a mean atomic weight of 21 (Fig. 7B), which can be attributed to more pervasive serpentinization relative to the Troodos and Oman peridotites.

A similar analysis using compressional-wave velocity data at 600 $\mathrm{MPa}$ in order to minimize the effects of microcrack porosity while enhancing the mineralogical contribution (Fig. 8), shows similar results for the lower crustal and upper mantle rocks of Hess Deep. The mean atomic weight lines were again corrected for a pressure of 600 MPa (Iturrino et al., 1995). These observations can perhaps be explained by different degrees of alteration in the gabbroic section and by the extensive serpentinization within the peridotites. These observations can also be illustrated by examining the variations in density and compressional-wave velocity as a function of the degree of alteration as calculated from thin-section analyses (Fig. 9A, B). The values of whole-rock alteration illustrated in these figures are derived from visual modal analyses, and could be more accurately quantified by image analysis and chemical characterization.

\section{Mineralogy and Velocity}

Even though most undeformed oceanic rocks contain large percentages of seismically anisotropic minerals, they tend to be isotropic or nearly isotropic because of the random orientation of their principal constituent minerals. High and low limits for the velocities of mineral aggregates having random grain orientations have been previously calculated from the mineral elastic constants assuming uniform strain and stress (Voigt, 1928; Reuss, 1929). Therefore, the VRH average, which is the mean of the Voigt-Reuss averages (Hill, 1952), can be used as the velocity of a monominerallic rock having a random grain orientation. Assuming random grain orientation, the data from Hess Deep should fall in a triangular field defined by the VRH averages of the principal constituent minerals.

A velocity-density plot at $200 \mathrm{MPa}$ for measured and calculated $\mathrm{Vp}$ values indicates that most of the gabbroic samples fall in a region defined by the VRH averages of plagioclase $\left(\mathrm{An}_{56}\right)$, olivine, and hornblende (Fig. 10A). These measurements are consistent with the average mineral proportions of these gabbros and olivine gabbros. However, most of the peridotite samples fall outside the field defined by the serpentine, olivine, and clinopyroxene VRH averages (Fig. 10B). The deviations from the mineralogically defined fields may be caused by either anisotropy produced by preferred mineral and microfracture orientations or alteration products.

Several of the measured and calculated velocity values for the gabbroic section fall below the plagioclase-hornblende line defining the VRH field, suggesting possible plagioclase and/or amphibole preferred orientation. Velocity anisotropy has also been observed between vertical and horizontal minicore pairs (Fig. 11A). These measurements show the vertical samples varying from faster to slower compressional-wave velocities when compared to their horizontal counterparts. In contrast, the peridotite samples exhibit mostly faster horizontal velocities (Fig. 11B). Preliminary thin-section observations show that preferred plagioclase orientation is responsible for some of the faster vertical and slower horizontal velocities in the gabbroic samples (Fig. 12A). This type of preferred plagioclase orientation seems to be similar to that observed in Hole 735B where the [010] direction produces fast vertical velocities. Most of the Hess Deep peridotites show preferred subhorizontally oriented foliation defined by the serpentine fabric which seems to contribute to the slower vertical velocities (Fig. 12B). While olivine appears to have a preferred orientation which may also contribute to the observed velocity anisotropy, intense alteration makes absolute determination of the preferred mineral orientation difficult.

Shear-wave splitting has also been observed in some of the rocks from Hess Deep. For example, troctolite Sample 147-895E-1R-1, $122-124 \mathrm{~cm}$, is characterized by shear-wave splitting measured at $100 \mathrm{MPa}$, which produces Vs anisotropy of up to $6 \%$ for a single propagation direction (Fig. 13A). For this particular sample, thin-section observations reveal a preferred olivine orientation which produces faster shear-wave velocities vibrating perpendicular $(V s 2=V s o)$ to the foliation and slower parallel (Vs1 = Vsp) to the foliation (Fig. $13 \mathrm{~B}$ ). The foliation dips approximately $37^{\circ}$ with respect to a horizontal plane.

Finally, the effects of the serpentinization on the reflectivity of the lower crust/upper mantle boundary have been examined with a simplistic model. A sequence of seven 50-m-thick layers was used to calculate a normal incidence reflection synthetic seismogram with no multiples included (Fig. 14). The input model consists of alternating gabbro and peridotite layers showing an increasing degree of serpentinization. The physical properties of the gabbroic layers were chosen to remain constant with velocities and densities approximating a rock with $40 \%$ degree of alteration whereas physical properties of the peridotite layers were calculated for $100 \%, 50 \%$, and $0 \%$ serpentinization, respectively. The $40 \%$ degree of alteration for the lower crustal rocks represents the average value observed in the Hess Deep gabbroic section recovered during Leg 147 whereas the $100 \%$ to $50 \%$ alteration values correspond to the range observed in the upper mantle rocks with the $0 \%$ degree of alteration representing a fresh peridotite mantle. This model shows the largest acoustic impedance contrast between the $40 \%$ altered lower crust and the $100 \%$ serpentinized upper mantle, which emulates the conditions drilled at the Hess Deep. The acoustic impedance contrast between a $40 \%$ altered lower crust and a $50 \%$ serpentinized upper mantle is much lower and the reflections are relatively small. Finally, the same lower crustal parameters produce significant acoustic impedance contrasts and reflections when overlying unaltered upper mantle conditions. However, the acoustic impedance contrast produced by a $40 \%$ altered lower crust and an unaltered upper mantle is smaller than results obtained from the $100 \%$ serpentinized upper mantle. These results would be even smaller if an unaltered lower crustal section was used for the model instead of the altered segment. 

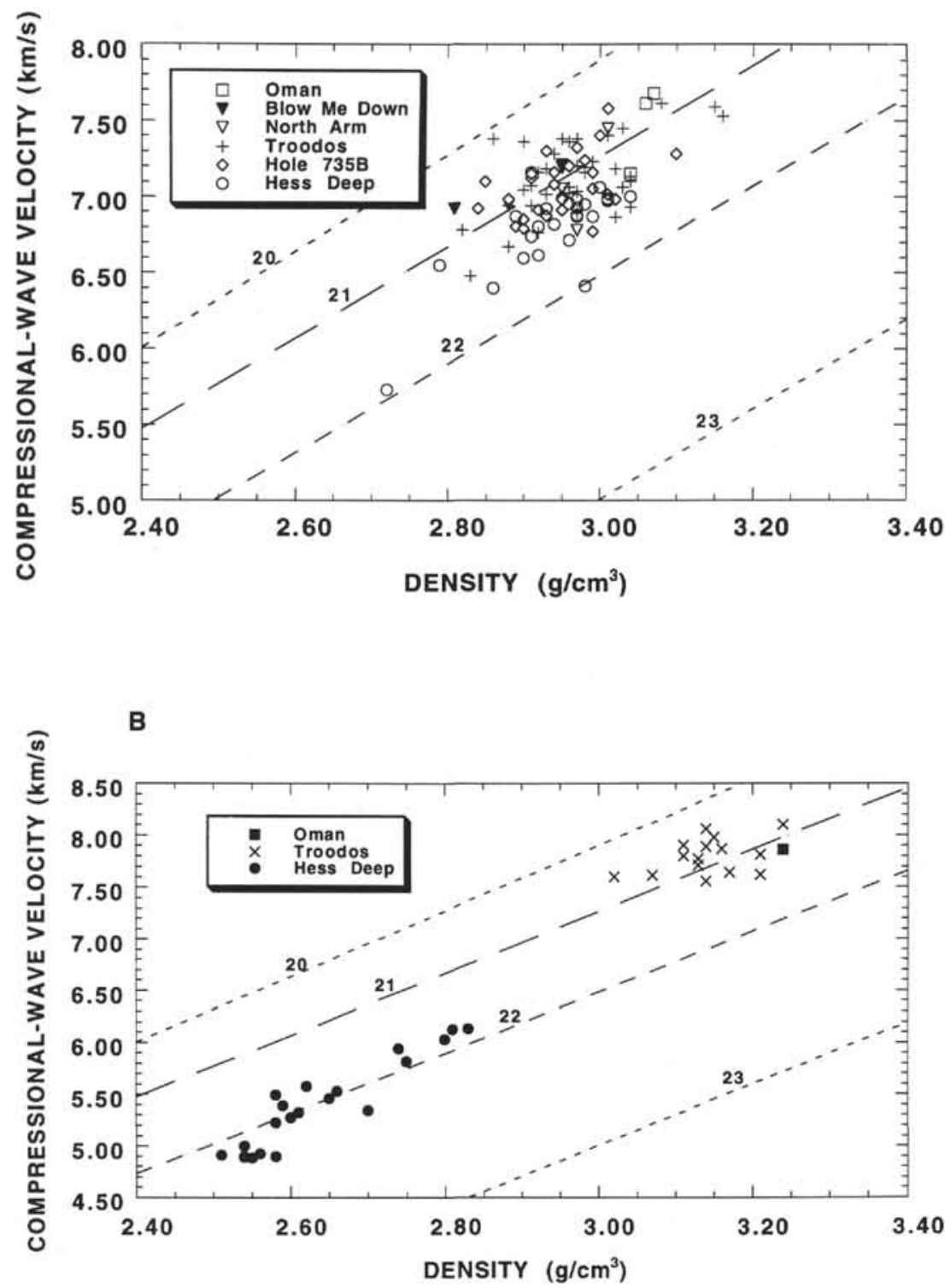

Figure 7. A. Density-Vp systematics for lower crustal gabbroic rocks from Hess Deep, Hole 735B, the Oman ophiolite, the Bay of Islands Blow Me Down and North Arm massifs, and Hole CY-4 in the Troodos complex. Velocities measured at $200 \mathrm{MPa}$ and mean atomic weight (MAW) lines corrected for pressure effects according to Birch's Law are also shown. B. Density-Vp systematics and lines of constant mean atomic weight for upper mantle rocks from Oman, Troodos, and Site 895. Velocities measured at $200 \mathrm{MPa}$; MAW corrected for pressure effects as in (A).

\section{Elastic Constants}

$\mathrm{Vp} / \mathrm{Vs}$ ratios, Poisson's ratios $(\sigma)$, bulk moduli $(\mathrm{K})$, and shear moduli $(\mu)$ calculated at selected pressures from measured densities and velocities are given in Table 3 , along with mineral modes calculated from thin-section point counts. These values are important for drilling considerations, because in a general way, rock fracture strength is proportional to the elastic moduli. In all cases, pre-existing fractures reduce the effective elastic stiffness and serve as sources of macroscopic failure by fracturing under the drill bit. These parameters can assist drilling engineers and scientists when making loadpressure decisions and bit selections and may also allow them to better estimate the life span of a core bit when drilling in fracture zones and deep crustal sections. The elastic moduli were defined and calculated in the following manner:

$$
\begin{gathered}
\sigma=(\text { lateral contraction }) \times(\text { longitudinal extension })^{-1} \\
=\left(\mathrm{Vp}^{2}-2 \mathrm{Vs}^{2}\right) /\left[2\left(\mathrm{Vp}^{2}-\mathrm{Vs}^{2}\right)\right], \\
\mathrm{K}=(\text { change in pressure }) \times(\text { change in volume })^{-1} \\
=\rho\left[\mathrm{Vp}^{2}-(4 / 3) \mathrm{Vs}^{2}\right], \\
\mu=(\text { shear stress }) \times(\text { shear strain })^{-1}=\rho \mathrm{Vs}^{2},
\end{gathered}
$$

where $\mathrm{Vp}=$ compressional-wave velocity, $\mathrm{Vs}=$ shear-wave velocity, and $\rho=$ density.

The $\mathrm{Vp} / \mathrm{Vs}$ ratio is a parameter widely used by seismologists for interpreting seismic data and Poisson's ratio is a measure of the lat- 
Table 2. Statistical analyses of ophiolite, Hole 735B, and Hess Deep lower crustal and upper mantle physical properties data.

\begin{tabular}{|c|c|c|c|c|c|c|c|c|c|}
\hline Locality & Lithology & $\begin{array}{l}\text { Mean density } \\
\left(\mathrm{g} / \mathrm{cm}^{3}\right)\end{array}$ & $\begin{array}{l}\text { Standard } \\
\text { deviation }\end{array}$ & Variance & Median & $\begin{array}{l}\text { Mean Vp } \\
(\mathrm{km} / \mathrm{s})\end{array}$ & $\begin{array}{l}\text { Standard } \\
\text { deviation }\end{array}$ & Variance & Median \\
\hline $\begin{array}{l}\text { Oman } \\
\text { (Christensen and Smewing, 1981) }\end{array}$ & $\begin{array}{l}\text { Gabbro and olivine gabbro } \\
\text { Peridotite }\end{array}$ & $\begin{array}{l}2.98(27) \\
2.95(4)\end{array}$ & $\begin{array}{l}0.08 \\
0.20\end{array}$ & $\begin{array}{l}0.007 \\
0.041\end{array}$ & $\begin{array}{l}2.99 \\
2.89\end{array}$ & $7.25(17)$ & 0.32 & 0.103 & 7.27 \\
\hline $\begin{array}{l}\text { Bay of Islands } \\
\text { Blow Me Down } \\
\text { North Arm } \\
\text { (Salisbury and Christensen, 1978; } \\
\text { Christensen and Salisbury; 1982) }\end{array}$ & $\begin{array}{l}\text { Gabbro and olivine gabbroo } \\
\text { Gabbro and olivine gabbro } \\
\text { Peridotite }\end{array}$ & $\begin{array}{l}2.93(19) \\
2.94(21) \\
2.74(6)\end{array}$ & $\begin{array}{l}0.05 \\
0.04 \\
0.15\end{array}$ & $\begin{array}{l}0.003 \\
0.002 \\
0.021\end{array}$ & $\begin{array}{l}2.95 \\
2.95 \\
2.74\end{array}$ & $\begin{array}{l}7.02(14) \\
7.12(14)\end{array}$ & $\begin{array}{l}0.19 \\
0.25\end{array}$ & $\begin{array}{l}0.037 \\
0.062\end{array}$ & $\begin{array}{l}7.02 \\
7.13\end{array}$ \\
\hline $\begin{array}{l}\text { Troodos (CY-4) } \\
\text { (Christensen and Salisbury, 1989) }\end{array}$ & $\begin{array}{l}\text { Gabbro and hornblende-gabbro } \\
\text { Websterite and olivine websterite }\end{array}$ & $\begin{array}{l}2.97(36) \\
3.14(15)\end{array}$ & $\begin{array}{l}0.07 \\
0.06\end{array}$ & $\begin{array}{l}0.005 \\
0.003\end{array}$ & $\begin{array}{l}2.97 \\
3.14\end{array}$ & $\begin{array}{l}7.18(36) \\
7.80(15)\end{array}$ & $\begin{array}{l}0.21 \\
0.17\end{array}$ & $\begin{array}{l}0.087 \\
0.03\end{array}$ & $\begin{array}{l}6.87 \\
7.80\end{array}$ \\
\hline $\begin{array}{l}\text { ODP Hole 735B } \\
\text { (Iturrino et al., 1991) }\end{array}$ & Gabbro and olivine gabbro & $2.95(28)$ & 0.06 & 0.003 & 2.95 & $7.07(28)$ & 0.20 & 0.037 & 7.03 \\
\hline Hess Deep & $\begin{array}{l}\text { Gabbro and olivine gabbro } \\
\text { Peridotite }\end{array}$ & $\begin{array}{l}2.92(51) \\
2.63(49)\end{array}$ & $\begin{array}{l}0.09 \\
0.10\end{array}$ & $\begin{array}{l}0.008 \\
0.011\end{array}$ & $\begin{array}{l}2.94 \\
2.59\end{array}$ & $\begin{array}{l}6.78(21) \\
5.39(21)\end{array}$ & $\begin{array}{l}0.29 \\
0.43\end{array}$ & $\begin{array}{l}0.087 \\
0.185\end{array}$ & $\begin{array}{l}6.87 \\
5.35\end{array}$ \\
\hline
\end{tabular}

Note: Amount of samples used for the mean calculation is shown in parentheses. Statistical figures based on velocities measured at $200 \mathrm{MPa}$.

eral contraction with respect to the longitudinal extension for a rock under stress. Vp-Vs plots at 200 and $600 \mathrm{MPa}$ (Fig. 15A, B) show that most the gabbroic samples from Hess Deep fall in a region bounded by lines of constant Poisson's ratio which correlates well with samples from Hole 735B $(\sigma=0.25$ to 0.30$)$. The peridotites display much higher values which are consistent with previously obtained upper mantle values (Christensen, 1974).

Poisson's ratio seems to remain relatively constant with changes in pressure above lower crustal conditions.

\section{SUMMARY}

Physical properties measurements obtained from Hess Deep samples recovered during ODP Leg 147 reveal the following conclusions regarding the nature of the lower oceanic crust and upper mantle near the Pacific-Cocos-Nazca triple junction:

1. The microcrack porosity obtained for the lower crustal gabbroic samples from Hess Deep correlates with the higher values measured from the metagabbros recovered from ODP Hole $735 \mathrm{~B}$. The high degree of alteration of the Hess Deep samples, as calculated from thin-section analyses, is believed to be responsible for the higher porosity values. The porosity-density relationship of the harzburgites shows more scatter and a steeper slope than the dunites which generally display relatively constant low density values and higher porosities. The difference in slopes is probably related to olivine:orthopyroxene ratios as well as the olivine content and the amount of serpentinization in these rocks.

2. Velocity and density systematics show a difference between the less altered ophiolite and Hole 735B samples and the altered Hess Deep gabbros. Variations in mean atomic weight in the gabbroic section are most likely due to the significant amount of amphibole, epidote, and phrenite veins present in these samples. The peridotites from Hess Deep show a much larger deviation from the mean atomic weight value of 21 , which can perhaps be attributed to the pervasive serpentinization exhibited by these samples. The serpentinization process may also be a significant factor in controlling the reflectivity of the Moho.

3. Compressional-wave anisotropy has been recorded in the gabbroic section recovered from Hess Deep. This anisotropy, which varies from fast to slow in the vertical orientation, is a product of preferred plagioclase orientation and perhaps preferred amphibole orientation. Shear-wave splitting has also been measured in a troctolite sample which shows preferred olivine orientation.

4. The peridotite samples also show velocity anisotropy with the faster $P$-wave velocity measurements recorded in the horizontal plane. In this case, the anisotropy is related to the preferred microcrack orientation responsible for the pervasive serpentine fabric. Shear-wave anisotropy has also been recorded between slower vertical minicores and their faster counterpart horizontal pairs.

5. Finally, Poisson's ratio values for the Hess Deep samples are consistent with previously obtained lower crustal and upper mantle values. The serpentinized peridotites of the intrarift ridge show higher values than the overlying altered gabbroic section. Above $200 \mathrm{MPa}$, pressure effects do not seem to affect Poisson's ratio.

\section{ACKNOWLEDGMENTS}

The authors would like to express their gratitude to Dr. Matthew Salisbury and Dr. Gregor Eberli for their careful reviews of the manuscript and their valuable comments. The authors would also like to thank Dr. Eberli for permitting the use of the high-pressure equipment in the RSMAS Petrophysics Laboratory. Special thanks to JOIUSSAC and the Office of Naval Research (ONR) for their financial support.

\section{REFERENCES}

ASTM, 1989. Annual Book of ASTM Standards for Soil and Rock: Building Stones (Vol. 4.08): Geotextiles: Philadelphia (American Society for Testing Materials).

Becker, K., 1991. In-situ bulk permeability of oceanic gabbros in Hole 735B, ODP Leg 118. In Von Herzen, R.P., Robinson, P.T., et al., Proc. ODP, Sci. Results, 118: College Station, TX (Ocean Drilling Program), 333347.

Birch, F., 1960. The velocity of compressional waves in rocks to 10 kilobars, I. J. Geophys. Res., 65:1083-1102.

, 1961. The velocity of compressional waves in rocks to 10 kilobars, 2. J. Geophys. Res., 66:2199-2224.

Christensen, N.I., 1965. Compressional-wave velocities in metamorphic rocks at pressures to 10 kilobars. J. Geophys. Res., 70:6147-6164.

- 1974. The petrologic nature of the lower oceanic crust and upper mantle. In Kristjansson, L. (Ed.), Geodynamics of Iceland and the North Atlantic Area. NATO ASI Ser., Ser. C:, 11:165-176.

, 1979. Compressional wave velocities in rocks at high temperatures and pressures, critical thermal gradients, and crustal low-velocity zones. J. Geophys. Res., 84:6849-6857. 
1982. Seismic velocities. In Carmichael, R.S. (Ed.), Handbook of Physical Properties of Rocks (Vol. 2): Boca Raton, FL (CRC Press), 1228.

1985. Measurements of dynamic properties of rocks at elevated temperatures and pressures. In Pincus, H.J., and Hoskins, E.R. (Eds.), Measurements of Rock Properties at Elevated Pressures and Temperatures: Philadelphia (American Society for Testing and Materials), ASTM STP 869:93-107.

Christensen, N.I., and Salisbury, M.H., 1982. Lateral heterogeneity in the seismic structure of the ocean crust inferred from velocity studies in the Bay of Islands ophiolite, Newfoundland. Geophys. J. R. Astron. Soc., 68:675-688.

1989. Velocity structure of the Troodos Massif, an arc-derived ophiolite. In Gibson, I.L., Malpas, J., Robinson, P.T., and Xenophontos, C. (Eds.), Cyprus Crustal Study Project: Initial Report, Hole CY-4. Geol. Surv. Can., 351-369.

Christensen, N.I., and Smewing, J., 1981. Geology and seismic structure of the northern section of the Oman ophiolite. J. Geophys. Res., 86:25452555.

Clauge, D.A., and Bunch, T.E., 1976. Formation of ferrobasalt at east Pacific mid-ocean spreading centers. J. Geophys. Res., 81:4247-4256.

Ewing, J., and Ewing, M., 1959. Seismic refraction measurements in the Atlantic Ocean basins, in the Mediterranean Sea, on the Mid-Atlantic ridge, and in the Norwegian Sea. Geol. Soc. Am. Bull., 70:291-318.

Gillis, K., Mével, C., Allan, J., et al., 1993. Proc. ODP, Init. Repts., 147: College Station, TX (Ocean Drilling Program).

Goldberg, D., Broglia, C., and Becker, K., 1991. Fracturing, alteration, and permeability: in-situ properties in Hole 735B. In Von Herzen, R.P., Robinson, P.T., et al., Proc. ODP, Sci. Results, 118: College Station, TX (Ocean Drilling Program), 261-269.

Hess, H.H., 1962. History of ocean basins. Geol. Soc. Am., Buddington Vol., 599-620.

Hill, R., 1952. The elastic behavior of a crystalline aggregate. Proc. Phys. Soc. London, Sect. A, 65:349-354.

Hyndman, R.D., and Drury, M.J., 1976. The physical properties of oceanic basement rocks from deep drilling on the Mid-Atlantic Ridge. J. Geophys. Res., 81:4042-4052.

Iturrino, G.J., Christensen, N.I., Becker, K., Boldreel, L.O., Harvey, P.H.K., and Pezard, P., 1995. Physical properties and elastic constants of upper crustal rocks from core-log measurements in Hole 504B. In Erzinger, J., Becker, K., Dick, H.J.B., and Stokking, L. (Eds.), Proc. ODP, Sci. Results, 137/140: College Station, TX (Ocean Drilling Program).

Iturrino, G.J., Christensen, N.I., Kirby, S., and Salisbury, M.H., 1991. Seismic velocities and elastic properties of oceanic gabbroic rocks from Hole 735B. In Von Herzen, R.P., Robinson, P.T., et al., Proc. ODP, Sci. Results, 118: College Station, TX (Ocean Drilling Program), 227-244.
Le Pichon, X., Houtz, R.E., Drake, C.L., and Nafe, J.E., 1965. Crustal structure of the mid-ocean ridges: seismic refraction measurements. J. Geophys. Res., 70:319-339.

Lewis, B.T.R., and Garmany, J.D., 1982. Constraints on the structure of the East Pacific Rise from seismic refraction data. J. Geophys. Res., 87:8417-8425.

Lonsdale, P., 1988. Structural pattern of the Galapagos microplate and evolution of the Galapagos triple junction. J. Geophys. Res., 93:13551-13574.

McCarthy, J., Mutter, J.C., Morton, J.L., Sleep, N.H., and Thompson, G.A., 1988. Relic magma chamber structures preserved within the Mesozoic North Atlantic crust? Geol. Soc. Am. Bull., 100:1423-1436.

Pezard, P.A., Howard, J.J., and Goldberg, D., 1991. Electrical conduction in oceanic gabbros, Hole 735B, Southwest Indian Ridge. In Von Herzen, R.P., Robinson, P.T., et al., Proc. ODP, Sci. Results, 118: College Station, TX (Ocean Drilling Program), 323-331.

Raitt, R.W., 1963. The crustal rocks. In Hill, M.N. (Ed.), The Sea: Ideas and Observations on Progress in the Study of the Seas (Vol. 3): New York (Wiley-Interscience), 3:85-102.

Reuss, A., 1929. Berechnung der Fliessgrenze von Mischkristallen auf Grund der Plastizitatsbedingung fur Einkristalle. Z. Agnew. Math. Mech., 9:49-54.

Salisbury, M.H., and Christensen, N.I., 1978. The seismic velocity structure of a traverse through the Bay of Islands ophiolite complex, Newfoundland, an exposure of oceanic crust and upper mantle. J. Geophys. Res., 83:805-817.

Schlumberger, 1989. Log Interpretation Principles/Applications: Houston, TX (Schlumberger Educ. Services).

Shor, G.G., Menard, H.W., and Raitt R.W., 1969. Regional observations: the structure of the Pacific basin. In Maxwell, A.E. (Ed.), The Sea: New York (Wiley), 4:3-27.

Sinton, J.M., and Detrick, R.S., 1992. Mid-ocean ridge magma chambers. J. Geophys. Res., 97:197-216.

Talwani, M., Le Pichon, X., and Ewing, M., 1965. Crustal structure of the mid-ocean ridges: computed model from gravity and seismic refraction data. J. Geophys. Res., 70:341-352.

Thy, P., Schiffman, P., and Moores, E.M., 1989. Igneous mineral stratigraphy and chemistry of the Cyprus Crustal Study Project drill core in the plutonic sequences of the Troodos Ophiolite. In Gibson, I.L., Malpas, J., Robinson, P.T., and Xenophontos, C. (Eds.), Cyprus Crustal Study Project: Initial Report, Hole CY-4. Pap.-Geol. Surv. Can., 88-9:147185.

Voigt, W., 1928. Lehrbuch der Kristallphysik: Leipzig (B.G. Teulner).

Date of initial receipt: 3 August 1994

Date of acceptance: 23 January 1995

Ms 147SR-027

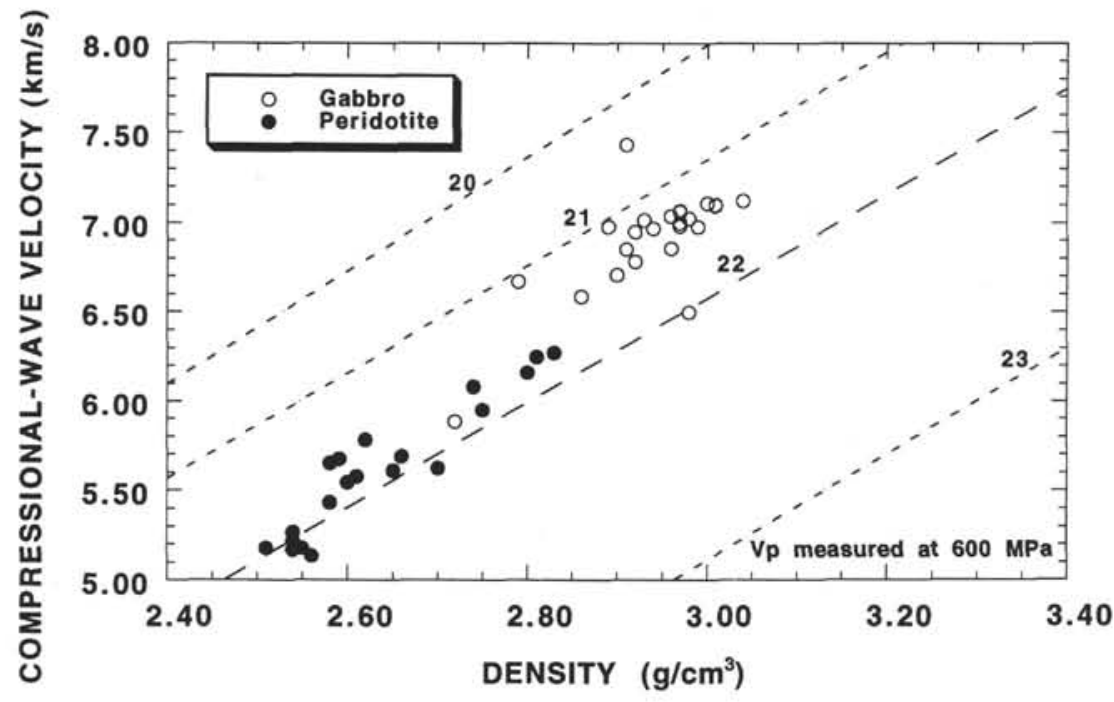

Figure 8. Density-Vp systematics for the lower crustal and upper mantle rocks from Hess Deep recovered during Leg 147 . Velocities measured at $600 \mathrm{MPa}$ to minimize the effects of microcrack porosity. MAW lines corrected for this pressure value according to Birch's Law. 
A

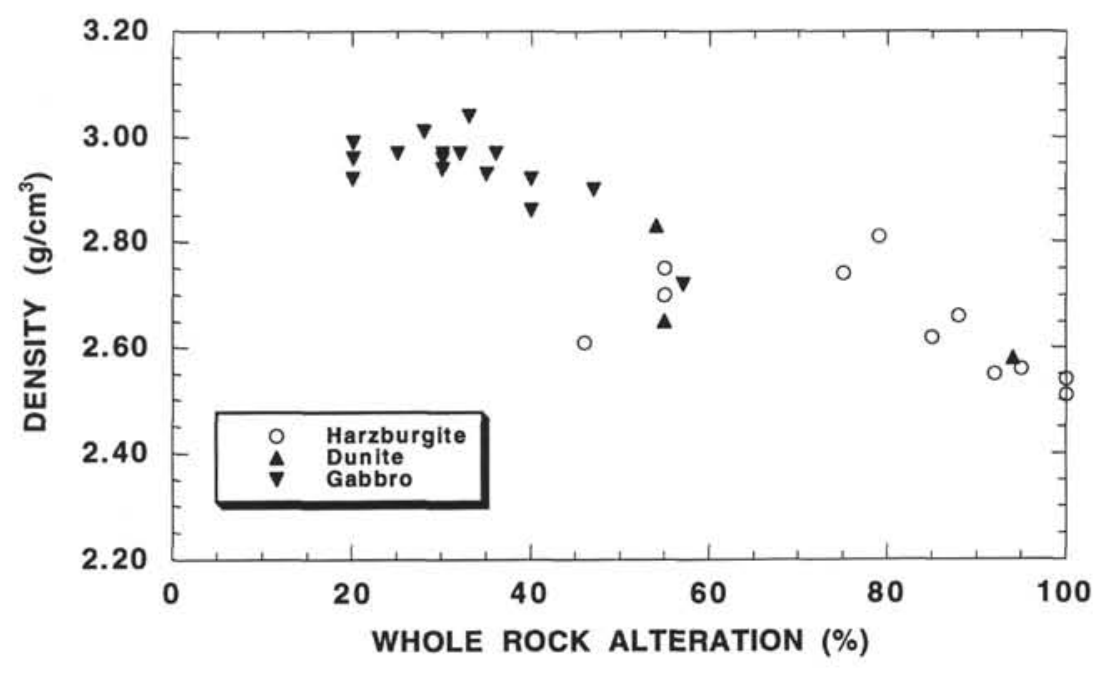

B

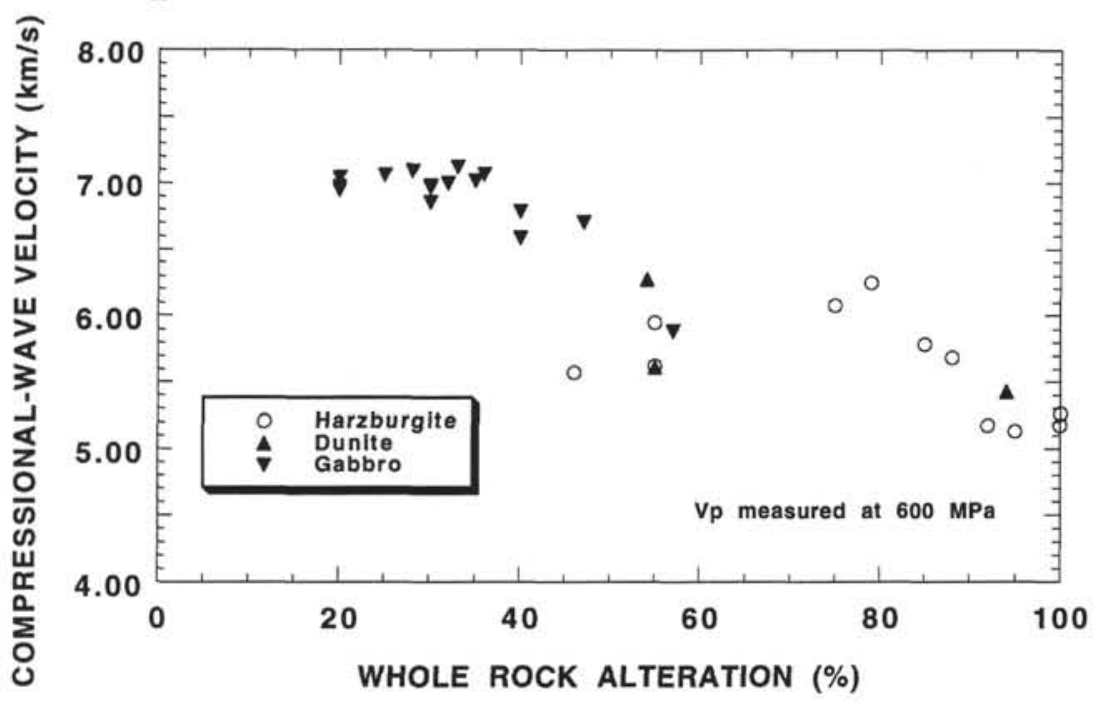

Figure 9. A. Density vs. $\%$ alteration for the rocks from Sites 894 and 895 . Alteration percentages were determined from mineral modes and thin-section analyses. B. The effects of alteration on compressional-wave velocities measured at $600 \mathrm{MPa}$ for the gabbro and peridotite samples from Hess Deep. 


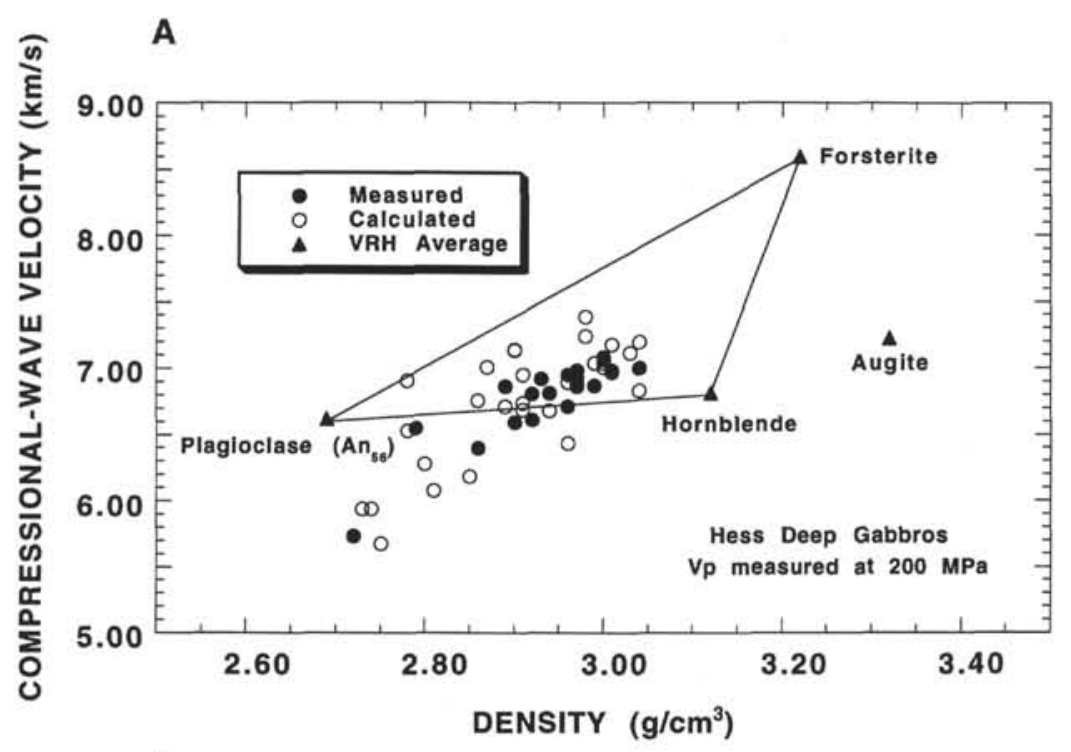

B

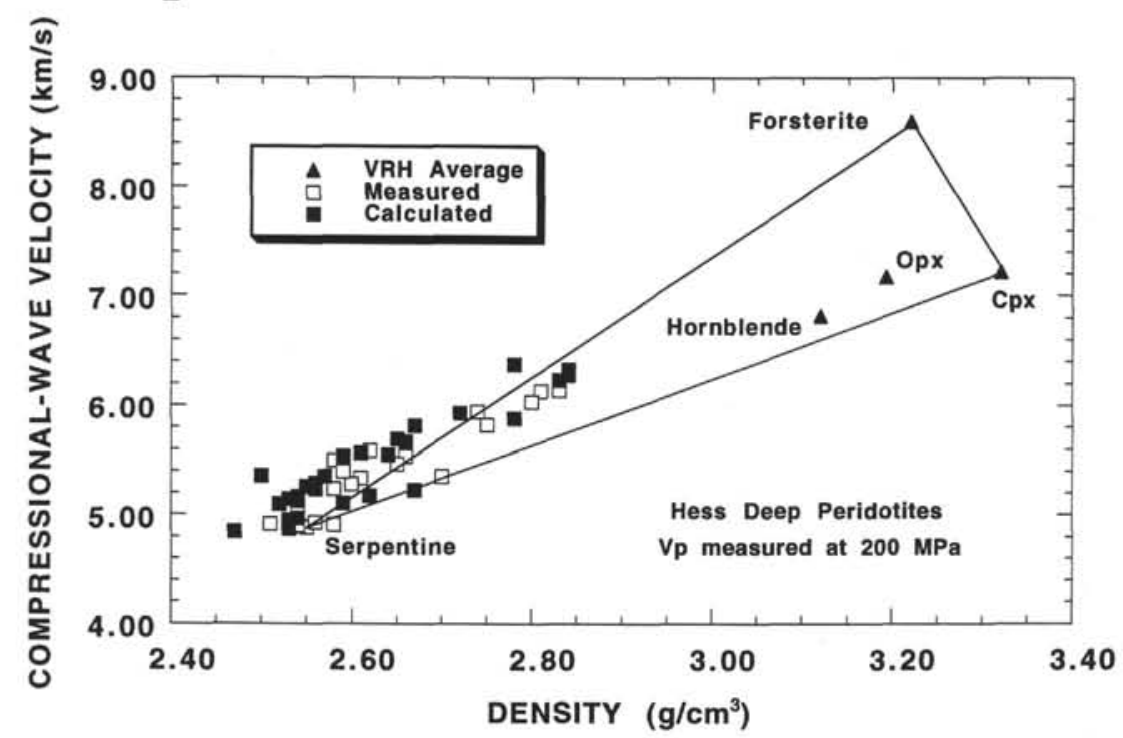

Figure 10. Compressional-wave velocity vs. density for gabbro (A) and peridotite samples from Hess Deep (B). Also shown are velocity-density fields for gabbro (A) and peridotite (B) based on VRH averages for principal constituent minerals (Christensen, 1982). 


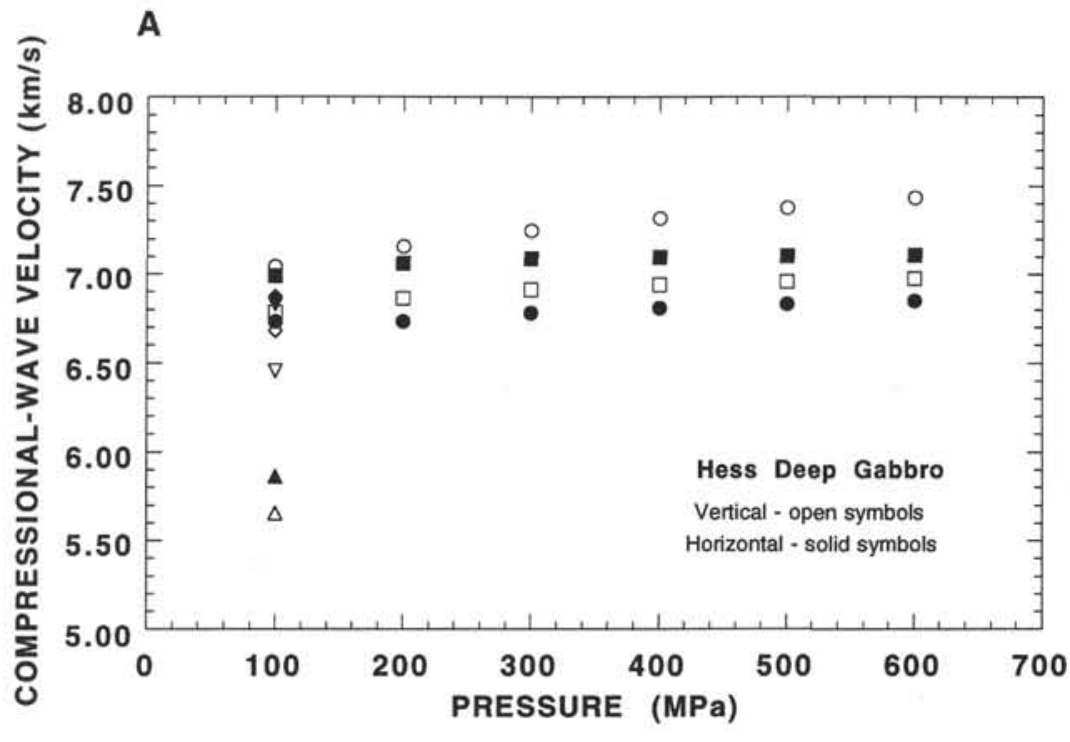

B

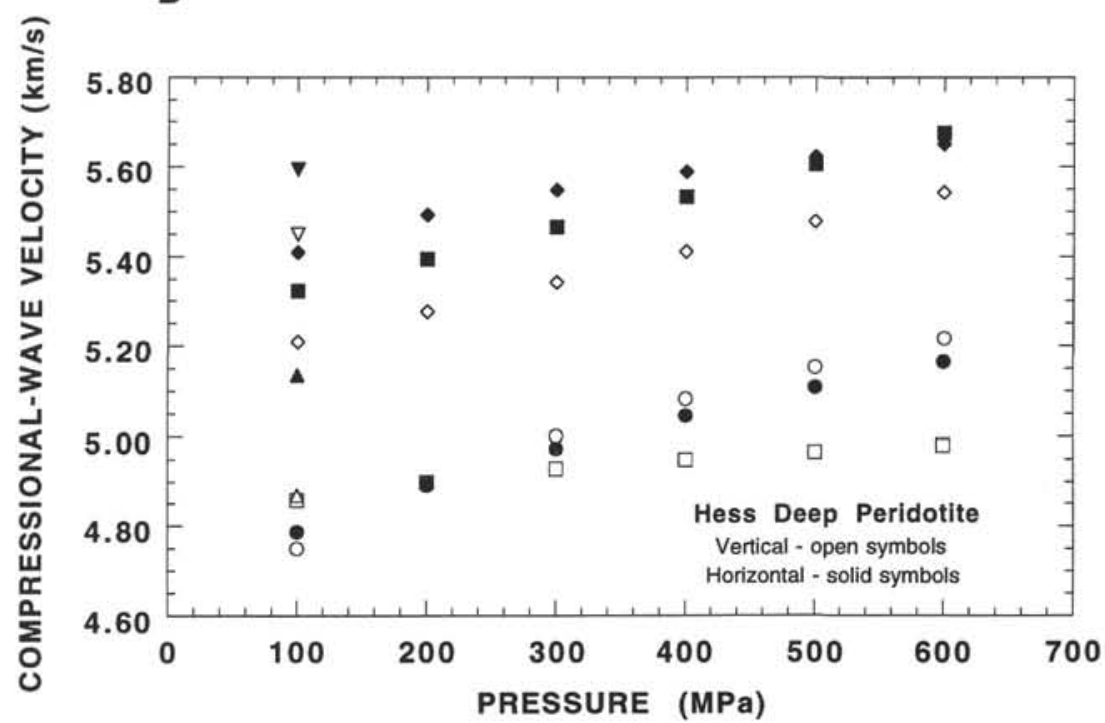

Figure 11. Compressional-wave velocity as a function of confining pressure for (A) gabbro and (B) peridotite vertical and horizontal minicore pairs showing variations in velocity anisotropy. 

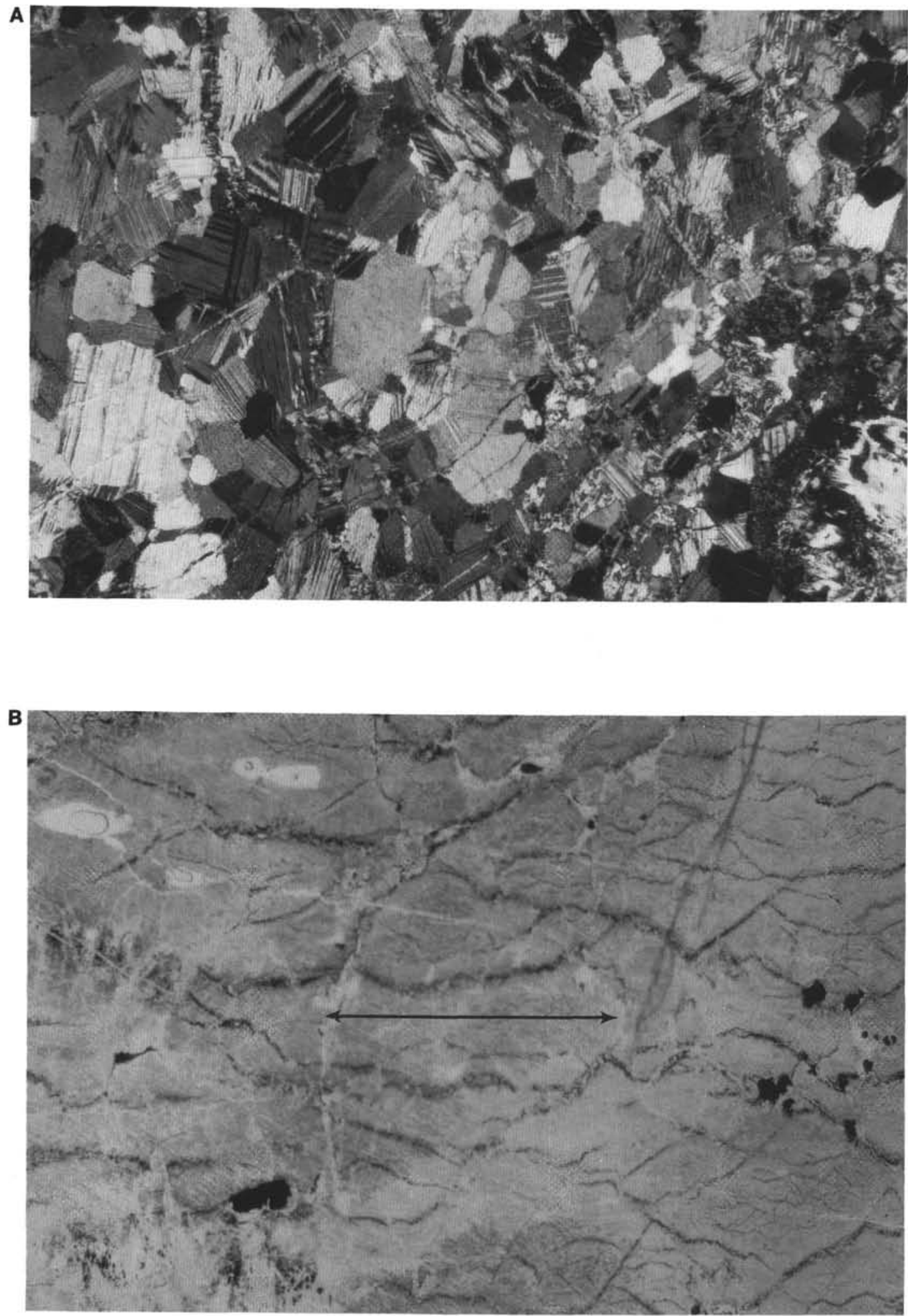

Figure 12. A. Photomicrograph of vertical minicore 147-895E-1R-1,36-41 cm, showing the systematic plagioclase orientation observed in a horizontal plane in some of the Hess Deep gabbroic samples. Field of view is $2.0 \mathrm{~cm}$. B. Photomicrograph of horizontal minicore 147-895E-6R-2, 111-113 cm, showing subhorizontally oriented serpentine fabric observed in a vertical plane in the peridotite samples. Arrow indicates the approximate microfracture preferred orientation. Field of view is $2.0 \mathrm{~cm}$. 
A
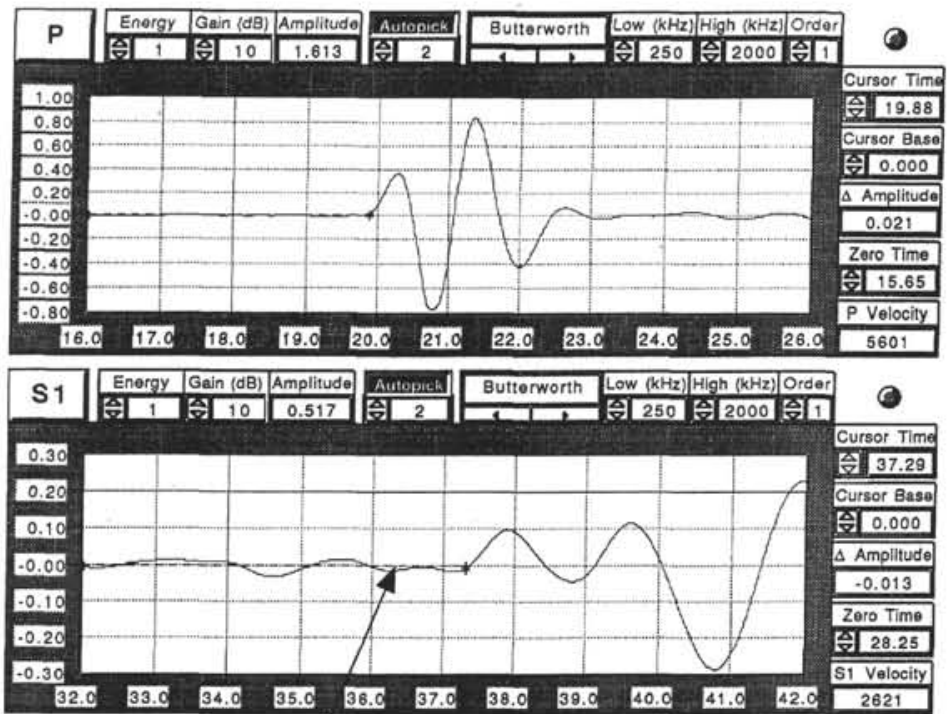

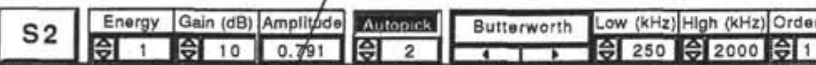

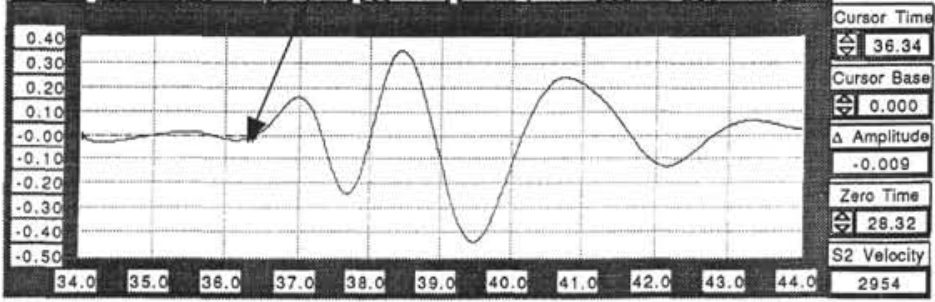

B

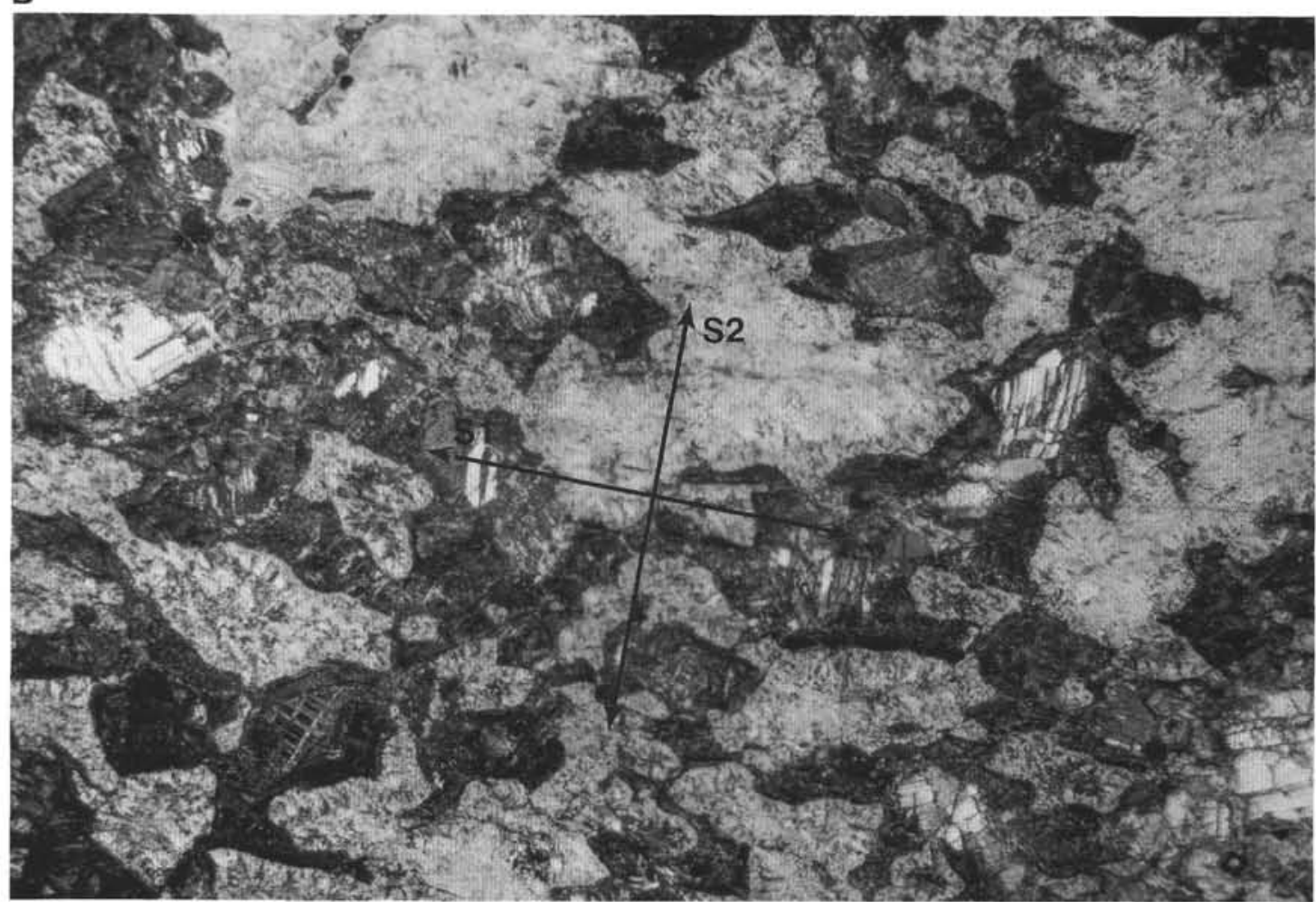

Figure 13. A. Shear-wave splitting observed in troctolite Sample 147-895E-1R-3, 122-124 cm. In this particular sample, S1 represents a shear-wave vibrating parallel to the foliation, whereas S2 symbolizes a vibration direction orthogonal to the fabric. The arrow shows the location of the S1 travel time if mineral orientation did not produce shear-wave splitting. B. The photomicrograph shows the systematic olivine alignment responsible for the Vs anisotropy. Arrows indicate vibration directions for both $\mathrm{S} 1$ and $\mathrm{S} 2$. Field of view is $2.0 \mathrm{~cm}$. 
Velocity Profile $(\mathrm{m} / \mathrm{s})$

Depth (mbsf)

Density Profile (g/cc)

Acoustic Impedance

Lithology

Reflection Coefficients

Ricker Wavelet: 0-degree phase; frequency: $30 \mathrm{~Hz}$; period: $26 \mathrm{~ms}$

Normal Polarity

Reverse Polarity

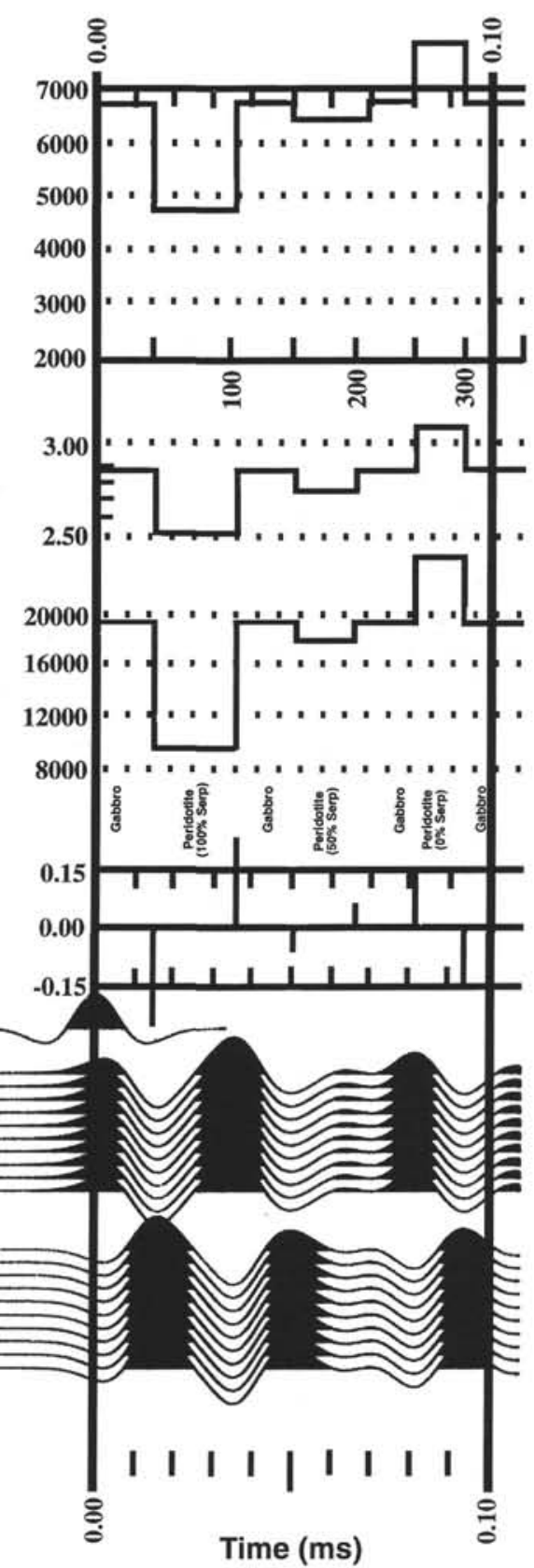

Time (ms)

Figure 14. Synthetic seismogram of a seven-layer gabbro-peridotite model constructed from 200-MPa velocity data using a 30-Hz Ricker wavelet. A large acoustic impedance contrast exists between $40 \%$ altered lower crustal layers and upper mantle sequences consisting of $100 \%$ and $0 \%$ serpentinized peridotite, but the contrast is low for serpentinized peridotite. 
Table 3. Average compressional- and shear-wave velocities as well as elastic constants and mineral modes for lower crustal and upper mantle rocks from Hess Deep.

\begin{tabular}{|c|c|c|c|c|c|c|c|c|c|c|c|c|}
\hline \multirow[b]{2}{*}{ Core, section, interval $(\mathrm{cm})$} & \multirow{2}{*}{$\begin{array}{l}\text { Elastic }- \\
\text { constants }\end{array}$} & \multicolumn{10}{|c|}{ Pressure (MPa) } & \multirow[b]{2}{*}{ Comments } \\
\hline & & 20 & 40 & 60 & 80 & 100 & 200 & 300 & 400 & 500 & 600 & \\
\hline $\begin{array}{c}147-894 \mathrm{~F}-2 \mathrm{R}-1(21-23) \\
\rho=2.93 \mathrm{~g} / \mathrm{cm}^{3}\end{array}$ & $\underset{\sigma}{\mathrm{Vp} / \mathrm{Vs}}$ & $\begin{array}{l}1.87 \\
0.25\end{array}$ & $\begin{array}{l}1.81 \\
0.23\end{array}$ & $\begin{array}{l}1.78 \\
0.22\end{array}$ & $\begin{array}{l}1.77 \\
0.22\end{array}$ & $\begin{array}{l}1.77 \\
0.21\end{array}$ & $\begin{array}{l}1.78 \\
0.22\end{array}$ & $\begin{array}{l}1.79 \\
0.22\end{array}$ & $\begin{array}{l}1.80 \\
0.22\end{array}$ & $\begin{array}{l}1.80 \\
0.23\end{array}$ & $\begin{array}{l}1.81 \\
0.23\end{array}$ & $\begin{array}{l}\text { Unit } 1 \text { Piece } 2 \\
\text { Plag } 51 \% \text { ( } 5 \% \text { alt), cpx } 47 \% \text { ( } 35 \% \text { alt mainly to amph), magnetite } 2 \% \text { with some } \\
\text { lattice exolution. }\end{array}$ \\
\hline $\begin{array}{l}\phi=0.90 \\
\text { Relatively undeformed gabbro }\end{array}$ & $\begin{array}{l}\mathrm{K} \\
\mu\end{array}$ & $\begin{array}{l}0.71 \\
0.33 \\
\text { Texture }\end{array}$ & $\begin{array}{c}0.70 \\
0.36 \\
\text { Medium }\end{array}$ & $\begin{array}{l}0.70 \\
0.38 \\
\text { coarse }\end{array}$ & $\begin{array}{c}0.71 \\
0.39 \\
\text { ained, } h\end{array}$ & $\begin{array}{l}0.71 \\
0.40 \\
\text { idiomorph }\end{array}$ & $\begin{array}{l}0.74 \\
0.41 \\
\text { c granular }\end{array}$ & $\begin{array}{l}0.76 \\
0.41\end{array}$ & $\begin{array}{l}0.78 \\
0.41\end{array}$ & $\begin{array}{l}0.79 \\
0.41\end{array}$ & $\begin{array}{l}0.80 \\
0.41\end{array}$ & \\
\hline $\begin{array}{l}147-894 \mathrm{G}-2 \mathrm{R}-1(109-115) \\
\rho=2.90 \mathrm{~g} / \mathrm{cm}^{3}\end{array}$ & $\underset{\sigma}{\mathrm{Vp} / \mathrm{Vs}}$ & $\begin{array}{l}1.83 \\
0.24\end{array}$ & $\begin{array}{l}1.84 \\
0.24\end{array}$ & $\begin{array}{l}1.84 \\
0.24\end{array}$ & $\begin{array}{l}1.84 \\
0.24\end{array}$ & $\begin{array}{l}1.84 \\
0.24\end{array}$ & $\begin{array}{l}1.85 \\
0.24\end{array}$ & $\begin{array}{l}1.85 \\
0.24\end{array}$ & $\begin{array}{l}1.86 \\
0.25\end{array}$ & $\begin{array}{l}1.86 \\
0.25\end{array}$ & $\begin{array}{l}1.90 \\
0.26\end{array}$ & $\begin{array}{l}\text { Unit } 2 \text { Piece } 15 \\
\text { Phen } 8 \% \text {; plag } 75 \% \text {, ol } 25 \% \text {. Groundmass: plag } 45 \% \text {, cpx } 40 \% \text {, magn } 2 \% \text {, spinel } \\
1 \% \text {, mesostasis } 2 \% \text {. }\end{array}$ \\
\hline Highly plag ol phyric basalt & $\begin{array}{l}\mathrm{K} \\
\mu\end{array}$ & $\begin{array}{l}0.71 \\
0.36 \\
\text { Texturc }\end{array}$ & $\begin{array}{r}0.73 \\
0.36 \\
\text { porphyri }\end{array}$ & $\begin{array}{l}0.74 \\
0.36 \\
\text { subopt }\end{array}$ & $\begin{array}{l}0.74 \\
0.36 \\
c \text { fine-gr }\end{array}$ & $\begin{array}{l}0.75 \\
0.36 \\
\text { ined matrix }\end{array}$ & $\begin{array}{l}0.76 \\
0.36\end{array}$ & $\begin{array}{l}0.77 \\
0.36\end{array}$ & $\begin{array}{l}0.77 \\
0.37\end{array}$ & $\begin{array}{l}0.78 \\
0.37\end{array}$ & $\begin{array}{l}0.83 \\
0.37\end{array}$ & \\
\hline $\begin{array}{l}147-894 \mathrm{G}-2 \mathrm{R}-2(105-109) \\
\rho=2.90 \mathrm{~g} / \mathrm{cm}^{3} \\
\phi=0.34 \\
\text { Plag ol phyric basalt }\end{array}$ & $\begin{array}{c}\mathrm{Vp} / \mathrm{Vs} \\
\sigma \\
\mathrm{K} \\
\mu\end{array}$ & $\begin{array}{l}1.87 \\
0.25 \\
0.75 \\
0.34 \\
\text { Texture }\end{array}$ & $\begin{array}{r}1.87 \\
0.25 \\
0.75 \\
0.35 \\
\text { fine-grai }\end{array}$ & $\begin{array}{c}1.86 \\
0.25 \\
0.76 \\
0.35 \\
\text { d plagio }\end{array}$ & $\begin{array}{l}1.84 \\
0.24 \\
0.75 \\
0.37 \\
\text { se and p }\end{array}$ & roxene gro & indmass & & & & & $\begin{array}{l}\text { Unit } 2 \text { Piece } 15 \\
\text { Groundmass: plag } 45 \% \text { with }-5 \% \text { alt., pxy }-55 \% \text { with }-30 \% \text { alt. Veins present. }\end{array}$ \\
\hline $\begin{array}{l}147-894 \mathrm{G}-2 \mathrm{R}-2(110-112) \\
\rho=2.91 \mathrm{~g} / \mathrm{cm}^{3} \\
\phi=0.14 \% \\
\text { Plag ol phyric basalt }\end{array}$ & $\begin{array}{l}\mathrm{Vp}_{\mathrm{p}} / \mathrm{Vs} \\
\sigma \\
\mathrm{K} \\
\mu\end{array}$ & $\begin{array}{c}1.81 \\
0.23 \\
0.72 \\
0.37 \\
\text { Texture }\end{array}$ & $\begin{array}{r}1.81 \\
0.23 \\
0.73 \\
0.38 \\
\text { fine-grai }\end{array}$ & $\begin{array}{c}1.81 \\
0.23 \\
0.73 \\
0.38 \\
\text { d plagio }\end{array}$ & $\begin{array}{c}1.82 \\
0.23 \\
0.75 \\
0.38 \\
\text { se and } p\end{array}$ & $\begin{array}{c}1.82 \\
0.23 \\
0.76 \\
0.39 \\
\text { roxene gro }\end{array}$ & Indmass & & & & & $\begin{array}{l}\text { Unit } 2 \text { Piece } 15 \\
\text { Groundmass: plag } 45 \% \text { with } \sim 5 \% \text { alt., pxy }-55 \% \text { with }-30 \% \text { alt. Veins present. }\end{array}$ \\
\hline $\begin{array}{l}147-894 \mathrm{G}-4 \mathrm{R}-1(91-93) \\
\rho=2.95 \mathrm{~g} / \mathrm{cm}^{3}\end{array}$ & $\underset{\sigma}{\mathrm{Vp} / \mathrm{Vs}}$ & $\begin{array}{l}1.87 \\
0.25\end{array}$ & $\begin{array}{l}1.82 \\
0.23\end{array}$ & $\begin{array}{l}1.81 \\
0.23\end{array}$ & $\begin{array}{l}1.79 \\
0.22\end{array}$ & $\begin{array}{l}1.79 \\
0.22\end{array}$ & $\begin{array}{l}1.79 \\
0.22\end{array}$ & $\begin{array}{l}1.80 \\
0.23\end{array}$ & $\begin{array}{l}1.80 \\
0.23\end{array}$ & $\begin{array}{l}1.80 \\
0.23\end{array}$ & $\begin{array}{l}1.80 \\
0.23\end{array}$ & $\begin{array}{l}\text { Unit } 4 \text { Piece } 13 \\
\text { Plag } 55 \% \text {; cp } 30 \% \text { (15\% alt), opx } 15 \% \text { ( } 5 \% \text { alt), both alt to amph and chl; } \\
\text { ilmenite }<2 \% \text {, sulfides }<<1 \% \text {. }\end{array}$ \\
\hline $\begin{array}{l}\phi=0.60 \\
\text { Gabbronorite }\end{array}$ & $\begin{array}{l}\mathrm{K} \\
\mu\end{array}$ & $\begin{array}{l}0.76 \\
0.36 \\
\text { Texture }\end{array}$ & $\begin{array}{r}0.76 \\
0.39 \\
\text { medium }\end{array}$ & $\begin{array}{l}0.78 \\
0.40 \\
\text { coarse }\end{array}$ & $\begin{array}{l}0.77 \\
0.41 \\
\text { ained hy }\end{array}$ & $\begin{array}{l}0.78 \\
0.41 \\
\text { idiomorphi }\end{array}$ & $\begin{array}{l}0.80 \\
0.42 \\
\text { granular, }\end{array}$ & $\begin{array}{r}0.81 \\
0.43 \\
\text { ophitic }\end{array}$ & $\begin{array}{c}0.83 \\
0.43 \\
\text { ubophit }\end{array}$ & $\begin{array}{c}0.83 \\
0.44 \\
\text { oriente }\end{array}$ & $\begin{array}{l}0.84 \\
0.44 \\
\text { agioclas }\end{array}$ & 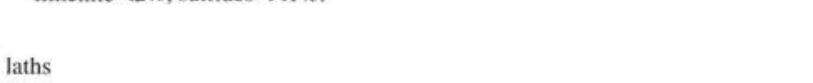 \\
\hline $\begin{array}{l}147-894 \mathrm{G}-7 \mathrm{R}-1(43-45) \\
\rho=2.97 \mathrm{~g} / \mathrm{cm}^{3}\end{array}$ & $\underset{\sigma}{\mathrm{Vp} / \mathrm{Vs}}$ & $\begin{array}{l}1.79 \\
0.22\end{array}$ & $\begin{array}{l}1.78 \\
0.22\end{array}$ & $\begin{array}{l}1.77 \\
0.21\end{array}$ & $\begin{array}{l}1.76 \\
0.21\end{array}$ & $\begin{array}{l}1.76 \\
0.21\end{array}$ & $\begin{array}{l}1.77 \\
0.22\end{array}$ & $\begin{array}{l}1.78 \\
0.22\end{array}$ & $\begin{array}{l}1.78 \\
0.22\end{array}$ & $\begin{array}{l}1.79 \\
0.22\end{array}$ & $\begin{array}{l}1.79 \\
0.22\end{array}$ & $\begin{array}{l}\text { Unit } 6 \text { Piece } 9 \\
\text { Plag } 60 \% \text { (10\% alt to amph), cpx } 20 \% \text { (10\% alt to amph and magn), opx } 15 \% \\
\text { (10\% alt to amph), magn } 1 \% \text {. }\end{array}$ \\
\hline $\begin{array}{l}\phi=0.91 \% \\
\text { Gabbronorite }\end{array}$ & $\begin{array}{l}\mathrm{K} \\
\mu\end{array}$ & $\begin{array}{l}0.72 \\
0.39 \\
\text { Texture }\end{array}$ & $\begin{array}{r}0.73 \\
0.40 \\
\text { medium }\end{array}$ & $\begin{array}{c}0.74 \\
0.41 \\
\text { coarse }\end{array}$ & $\begin{array}{l}0.74 \\
0.42 \\
\text { ained hy }\end{array}$ & $\begin{array}{l}0.75 \\
0.42 \\
\text { idiomorphi }\end{array}$ & $\begin{array}{l}0.77 \\
0.43 \\
\text { granular, }\end{array}$ & $\begin{array}{r}0.78 \\
0.43 \\
\text { ophitic }\end{array}$ & $\begin{array}{l}0.80 \\
0.43 \\
\text { ubophi }\end{array}$ & $\begin{array}{l}0.81 \\
0.43 \\
\sim 30 \%\end{array}$ & $\begin{array}{l}0.82 \\
0.43 \\
\text { amorphic }\end{array}$ & \\
\hline $\begin{array}{l}147-894 \mathrm{G}-8 \mathrm{R}-2(107-109) \\
\rho=2.98 \mathrm{~g} / \mathrm{cm}^{3}\end{array}$ & $\begin{array}{c}\mathrm{Vp} / \mathrm{Vs} \\
\sigma\end{array}$ & $\begin{array}{l}1.89 \\
0.25\end{array}$ & $\begin{array}{l}1.81 \\
0.23\end{array}$ & $\begin{array}{l}1.79 \\
0.22\end{array}$ & $\begin{array}{l}1.79 \\
0.22\end{array}$ & $\begin{array}{l}1.79 \\
0.22\end{array}$ & $\begin{array}{l}1.80 \\
0.23\end{array}$ & $\begin{array}{l}1.81 \\
0.23\end{array}$ & $\begin{array}{l}1.82 \\
0.23\end{array}$ & $\begin{array}{l}1.82 \\
0.23\end{array}$ & $\begin{array}{l}1.83 \\
0.24\end{array}$ & $\begin{array}{l}\text { Unit } 6 \text { Piece } 10 \\
\text { Plag } 55 \% \text { ( } 10 \% \text { alt to clay and amph); cpx } 35 \% \text { ( } 10 \% \text { alt), opx } 10 \% \text { ( } 5 \% \text { alt), both } \\
\text { alt to amph; magn <1\%. }\end{array}$ \\
\hline $\begin{array}{l}\phi=0.31 \% \\
\text { Gabbronorite }\end{array}$ & ${ }_{\mu}^{K}$ & $\begin{array}{l}0.82 \\
0.37 \\
\text { Texturc }\end{array}$ & $\begin{array}{r}0.80 \\
0.41 \\
\text { medium }\end{array}$ & $\begin{array}{r}0.80 \\
0.43 \\
\text { ained hy }\end{array}$ & $\begin{array}{c}0.81 \\
0.43 \\
\text { diomorp }\end{array}$ & $\begin{array}{l}0.82 \\
0.44 \\
\text { ic granular }\end{array}$ & $\begin{array}{c}0.84 \\
0.44 \\
\text { ophitic, h }\end{array}$ & $\begin{array}{c}0.86 \\
0.44 \\
\text { terogen }\end{array}$ & $\begin{array}{c}0.87 \\
0.44 \\
\text { is altera }\end{array}$ & $\begin{array}{c}0.88 \\
0.44 \\
\text { n, varial }\end{array}$ & $\begin{array}{l}0.89 \\
0.44 \\
\text { grain siz }\end{array}$ & \\
\hline $\begin{array}{l}147-894 \mathrm{G}-9 \mathrm{R}-1(37-39) \\
\rho=2.95 \mathrm{~g} / \mathrm{cm}^{3}\end{array}$ & $\underset{\sigma}{\mathrm{Vp} / \mathrm{Vs}}$ & $\begin{array}{l}1.87 \\
0.25\end{array}$ & $\begin{array}{l}1.82 \\
0.23\end{array}$ & $\begin{array}{l}1.79 \\
0.22\end{array}$ & $\begin{array}{l}1.79 \\
0.22\end{array}$ & $\begin{array}{l}1.78 \\
0.22\end{array}$ & $\begin{array}{l}1.78 \\
0.22\end{array}$ & $\begin{array}{l}1.78 \\
0.22\end{array}$ & $\begin{array}{l}1.79 \\
0.22\end{array}$ & $\begin{array}{l}1.79 \\
0.22\end{array}$ & $\begin{array}{l}1.79 \\
0.22\end{array}$ & $\begin{array}{l}\text { Unit } 6 \text { Piece } 6 \mathrm{~B} \\
\text { Plag } 60 \% \text { ( } 5 \% \text { alt); cpx } 30 \% \text { (20\% alt), opx } 10 \% \text { ( } 5 \% \text { alt), both alt to amph, magn } \\
<1 \% \text {, sulfides }<<1 \% \text {. }\end{array}$ \\
\hline $\begin{array}{l}\phi=0.63 \% \\
\text { Gabbronorite }\end{array}$ & $\begin{array}{l}\mathrm{K} \\
\mu\end{array}$ & $\begin{array}{l}0.78 \\
0.36 \\
\text { Textur }\end{array}$ & $\begin{array}{r}0.77 \\
0.39 \\
\text { medium }\end{array}$ & $\begin{array}{r}0.77 \\
0.41 \\
\text { ained hy }\end{array}$ & $\begin{array}{c}0.77 \\
0.41 \\
\text { diomorp }\end{array}$ & $\begin{array}{l}0.77 \\
0.42 \\
\text { c granular }\end{array}$ & $\begin{array}{l}0.79 \\
0.43 \\
\text { ophitic, st }\end{array}$ & $\begin{array}{r}0.81 \\
0.44 \\
\text { bophiti }\end{array}$ & $\begin{array}{c}0.82 \\
0.44 \\
\text { nd inter }\end{array}$ & $\begin{aligned} & 0.83 \\
& 0.45 \\
& \text { nular, } \mathrm{p}\end{aligned}$ & $\begin{array}{l}0.83 \\
0.45 \\
\text { ible mag }\end{array}$ & natic fol \\
\hline $\begin{array}{c}147-894 \mathrm{G}-9 \mathrm{R}-4(54-59) \\
\rho=2.97 \mathrm{~g} / \mathrm{cm}^{3}\end{array}$ & $\underset{\sigma}{\mathrm{Vp} / \mathrm{Vs}}$ & $\begin{array}{l}1.77 \\
0.21\end{array}$ & $\begin{array}{l}1.78 \\
0.22\end{array}$ & $\begin{array}{l}1.78 \\
0.22\end{array}$ & $\begin{array}{l}1.78 \\
0.22\end{array}$ & $\begin{array}{l}1.78 \\
0.22\end{array}$ & $\begin{array}{l}1.78 \\
0.22\end{array}$ & $\begin{array}{l}1.79 \\
0.22\end{array}$ & $\begin{array}{l}1.79 \\
0.22\end{array}$ & $\begin{array}{l}1.79 \\
0.22\end{array}$ & $\begin{array}{l}1.79 \\
0.22\end{array}$ & $\begin{array}{l}\text { Unit } 7 \text { Piece } 4 \\
\text { Plag } 55 \% \text { ( } 5 \% \text { alt); cpx } 35 \% \text { (25\% alt), opx } 5 \% \text { ( } 3 \% \text { alt); ol } 5 \% \text { ( } 3 \% \text { alt); opaques } \\
<1 \% \text {. Veins present. }\end{array}$ \\
\hline Olivine gabbronorite & $\begin{array}{l}\mathrm{K} \\
\mu\end{array}$ & $\begin{array}{l}0.80 \\
0.44 \\
\text { Texture }\end{array}$ & $\begin{aligned} 0.81 \\
0.45 \\
\text { medium }\end{aligned}$ & $\begin{array}{r}0.82 \\
0.45 \\
\text { ained, } p\end{array}$ & $\begin{array}{l}0.83 \\
0.45 \\
\text { ilitic }\end{array}$ & $\begin{array}{l}0.83 \\
0.45\end{array}$ & $\begin{array}{l}0.84 \\
0.46\end{array}$ & $\begin{array}{l}0.85 \\
0.46\end{array}$ & $\begin{array}{l}0.85 \\
0.46\end{array}$ & $\begin{array}{l}0.86 \\
0.46\end{array}$ & $\begin{array}{l}0.87 \\
0.46\end{array}$ & \\
\hline $\begin{array}{c}147-894 \mathrm{G}-10 \mathrm{R}-2(38-40) \\
\rho=3.01 \mathrm{~g} / \mathrm{cm}^{3}\end{array}$ & $\underset{\sigma}{\mathrm{Vp} / \mathrm{Vs}}$ & $\begin{array}{l}1.82 \\
0.23\end{array}$ & $\begin{array}{l}1.80 \\
0.23\end{array}$ & $\begin{array}{l}1.79 \\
0.22\end{array}$ & $\begin{array}{l}1.78 \\
0.22\end{array}$ & $\begin{array}{l}1.78 \\
0.22\end{array}$ & $\begin{array}{l}1.78 \\
0.22\end{array}$ & $\begin{array}{l}1.78 \\
0.22\end{array}$ & $\begin{array}{l}1.78 \\
0.22\end{array}$ & $\begin{array}{l}1.78 \\
0.22\end{array}$ & $\begin{array}{l}1.78 \\
0.22\end{array}$ & $\begin{array}{l}\text { Unit } 8 \text { Piece } 4 \\
\text { Plag } 55 \% \text { ( }<5 \% \text { alt); cpx } 38 \% \text { (20\% alt), opx } 5 \% \text { ( } 3 \% \text { alt); ol } 2 \% \text { (1\% alt) magn } \\
<1 \% \text {; ilm }<<1 \% \text {; sulfide }<<1 \% \text {. }\end{array}$ \\
\hline
\end{tabular}


Table 3 (continued).

\begin{tabular}{|c|c|c|c|c|c|c|c|c|c|c|c|c|}
\hline \multirow[b]{2}{*}{ Core, section, interval $(\mathrm{cm})$} & \multirow{2}{*}{$\begin{array}{l}\text { Elastic } \\
\text { constants }\end{array}$} & \multicolumn{10}{|c|}{ Pressure (MPa) } & \multirow[b]{2}{*}{ Comments } \\
\hline & & 20 & 40 & 60 & 80 & 100 & 200 & 300 & 400 & 500 & 600 & \\
\hline $\begin{array}{l}\phi=0.16 \% \\
\text { Gabbronorite }\end{array}$ & $\begin{array}{l}K \\
\mu\end{array}$ & $\begin{array}{l}0.82 \\
0.42 \\
\text { Texture }\end{array}$ & $\begin{array}{c}0.82 \\
0.43 \\
\text { nedium }\end{array}$ & $\begin{array}{r}0.82 \\
0.44 \\
\text { ained hy }\end{array}$ & $\begin{array}{c}0.83 \\
0.45 \\
\text { diomor }\end{array}$ & $\begin{array}{l}0.83 \\
0.46 \\
\text { e granula }\end{array}$ & $\begin{array}{l}0.85 \\
0.47 \\
\text { subophi }\end{array}$ & $\begin{array}{l}0.86 \\
0.47 \\
\text { no evic }\end{array}$ & $\begin{array}{l}0.87 \\
0.47 \\
\text { t deform }\end{array}$ & $\begin{array}{l}0.87 \\
0.47 \\
\text { ion }\end{array}$ & $\begin{array}{l}0.88 \\
0.48\end{array}$ & \\
\hline $\begin{array}{l}147-894 \mathrm{G}-11 \mathrm{R}-1(135-137) \\
\rho=2.90 \mathrm{~g} / \mathrm{cm}^{3}\end{array}$ & $\underset{\sigma}{\mathrm{Vp} / \mathrm{Vs}}$ & $\begin{array}{l}1.80 \\
0.23\end{array}$ & $\begin{array}{l}1.77 \\
0.22\end{array}$ & $\begin{array}{l}1.76 \\
0.21\end{array}$ & $\begin{array}{l}1.76 \\
0.21\end{array}$ & $\begin{array}{l}1.76 \\
0.21\end{array}$ & $\begin{array}{l}1.76 \\
0.21\end{array}$ & $\begin{array}{l}1.77 \\
0.22\end{array}$ & $\begin{array}{l}1.77 \\
0.22\end{array}$ & $\begin{array}{l}1.78 \\
0.22\end{array}$ & $\begin{array}{l}1.78 \\
0.22\end{array}$ & $\begin{array}{l}\text { Unit } 9 \text { Piece } 17 \mathrm{~B} \\
\text { Plag } 50 \% \text { (10\% alt); cpx } 40 \% \text { ( } 30 \% \text { alt), opx } 10 \% \text { ( } 7 \% \text { alt); ol }<2 \% \text { (almost } \\
\text { completely alt); mag }<1 \% \text {. }\end{array}$ \\
\hline $\begin{array}{l}\phi=0.68 \% \\
\text { Gabbronorite }\end{array}$ & $\begin{array}{l}\mathrm{K} \\
\mu\end{array}$ & $\begin{array}{c}0.68 \\
0.36 \\
\text { Texture }\end{array}$ & $\begin{array}{c}0.68 \\
0.38 \\
\text { nedium }\end{array}$ & $\begin{array}{l}0.69 \\
0.39 \\
\text { ained of }\end{array}$ & $\begin{array}{l}0.70 \\
0.40 \\
\text { tic, hyp }\end{array}$ & $\begin{array}{c}0.70 \\
0.40 \\
\text { omorphic }\end{array}$ & $\begin{array}{l}0.72 \\
0.40 \\
\text { alg and }\end{array}$ & $\begin{array}{l}0.73 \\
0.41 \\
\text { roxene }\end{array}$ & $\begin{array}{c}0.74 \\
0.41 \\
\text { ered to fil }\end{array}$ & $\begin{array}{l}0.75 \\
0.41 \\
\text {-graine }\end{array}$ & $\begin{array}{l}0.76 \\
0.41 \\
\text { mph and }\end{array}$ & \\
\hline $\begin{array}{l}147-894 \mathrm{G}-12 \mathrm{R}-5(108-112) \\
\rho=2.99 \mathrm{~g} / \mathrm{cm}^{3}\end{array}$ & $\underset{\sigma}{\mathrm{V}_{\mathrm{p}} / \mathrm{Vs}}$ & $\begin{array}{l}1.81 \\
0.23\end{array}$ & $\begin{array}{l}1.79 \\
0.22\end{array}$ & $\begin{array}{l}1.78 \\
0.22\end{array}$ & $\begin{array}{l}1.78 \\
0.22\end{array}$ & $\begin{array}{l}1.77 \\
0.22\end{array}$ & $\begin{array}{l}1.78 \\
0.22\end{array}$ & $\begin{array}{l}1.78 \\
0.22\end{array}$ & $\begin{array}{l}1.78 \\
0.22\end{array}$ & $\begin{array}{l}1.78 \\
0.22\end{array}$ & $\begin{array}{l}1.78 \\
0.22\end{array}$ & $\begin{array}{l}\text { Unit } 11 \text { Piece } 11 \mathrm{~A} \\
\text { Plag } 45 \% \text { ( } 5 \% \text { alt); } \operatorname{cpx} 30 \% \text { ( } 20 \% \text { alt), opx } 15 \% \text { (10\% alt), both alt to amph and } \\
\text { clay; magn <1\%; pyr }<<1 \% \text {. }\end{array}$ \\
\hline $\begin{array}{l}\phi=0.34 \% \\
\text { Gabbronorite }\end{array}$ & $\begin{array}{l}\mathrm{K} \\
\mu\end{array}$ & $\begin{array}{c}0.78 \\
0.40 \\
\text { Texture }\end{array}$ & $\begin{array}{c}0.78 \\
0.42 \\
\text { nedium }\end{array}$ & $\begin{array}{l}0.79 \\
0.43 \\
\text { coarse }\end{array}$ & $\begin{array}{r}0.79 \\
0.43 \\
\text { ained hy }\end{array}$ & $\begin{array}{c}0.79 \\
0.44 \\
\text { tiomorph }\end{array}$ & $\begin{array}{l}0.81 \\
0.45 \\
\text { granul: }\end{array}$ & $\begin{array}{c}0.82 \\
0.45 \\
\text { ophitic t }\end{array}$ & $\begin{array}{l}0.83 \\
0.45 \\
\text { subophitic }\end{array}$ & $\begin{array}{c}0.83 \\
0.45 \\
\text { heterog }\end{array}$ & $\begin{array}{l}0.84 \\
0.45 \\
\text { eously al }\end{array}$ & \\
\hline $\begin{array}{c}147-894 \mathrm{G}-12 \mathrm{R}-6(43-48) \\
\rho=2.97 \mathrm{~g} / \mathrm{cm}^{3}\end{array}$ & $\underset{\sigma}{\mathrm{Vp} / \mathrm{Vs}}$ & $\begin{array}{l}1.80 \\
0.23\end{array}$ & $\begin{array}{l}1.79 \\
0.22\end{array}$ & $\begin{array}{l}1.78 \\
0.22\end{array}$ & $\begin{array}{l}1.78 \\
0.22\end{array}$ & $\begin{array}{l}1.78 \\
0.22\end{array}$ & $\begin{array}{l}1.78 \\
0.22\end{array}$ & $\begin{array}{l}1.79 \\
0.22\end{array}$ & $\begin{array}{l}1.80 \\
0.22\end{array}$ & $\begin{array}{l}1.80 \\
0.23\end{array}$ & $\begin{array}{l}1.80 \\
0.23\end{array}$ & $\begin{array}{l}\text { Unit } 11 \text { Piece } 5 C \\
\text { Plag } 50 \% \text { ( } 5 \% \text { alt); cpx } 35 \% \text { ( } 25 \% \text { alt), opx } 15 \% \text { (10\% alt); magn }<1 \% \text { pyrite } \\
<<1 \% \text {. }\end{array}$ \\
\hline Gabbronorite & $\begin{array}{l}\mathrm{K} \\
\mu\end{array}$ & $\begin{array}{c}0.78 \\
0.41 \\
\text { Texture }\end{array}$ & $\begin{array}{c}0.78 \\
0.42 \\
\text { nedium }\end{array}$ & $\begin{array}{l}0.79 \\
0.43 \\
\text { coarse }\end{array}$ & $\begin{array}{r}0.79 \\
0.43 \\
\text { ained hy }\end{array}$ & $\begin{array}{l}0.80 \\
0.43 \\
\text { liomorph }\end{array}$ & $\begin{array}{l}0.81 \\
0.44 \\
\text { granul: }\end{array}$ & $\begin{array}{l}0.83 \\
0.44 \\
\text { phitic }\end{array}$ & $\begin{array}{l}0.84 \\
0.44 \\
\text { subophitic }\end{array}$ & $\begin{array}{l}0.85 \\
0.44\end{array}$ & $\begin{array}{l}0.85 \\
0.45\end{array}$ & \\
\hline $\begin{array}{c}147-894 \mathrm{G}-13 \mathrm{R}-1(86-89) \\
\rho=3.04 \mathrm{~g} / \mathrm{cm}^{3}\end{array}$ & $\underset{\sigma}{\mathrm{Vp} / \mathrm{Vs}}$ & $\begin{array}{l}1.77 \\
0.22\end{array}$ & $\begin{array}{l}1.77 \\
0.21\end{array}$ & $\begin{array}{l}1.77 \\
0.21\end{array}$ & $\begin{array}{l}1.76 \\
0.21\end{array}$ & $\begin{array}{l}1.76 \\
0.21\end{array}$ & $\begin{array}{l}1.76 \\
0.21\end{array}$ & $\begin{array}{l}1.77 \\
0.21\end{array}$ & $\begin{array}{l}1.77 \\
0.22\end{array}$ & $\begin{array}{l}1.75 \\
0.21\end{array}$ & $\begin{array}{l}1.77 \\
0.22\end{array}$ & $\begin{array}{l}\text { Unit } 11 \text { Piece } 11 \mathrm{~B} \\
\text { Plag } 53 \% \text { ( } 10 \% \text { alt); cpx } 30 \% \text { (15\% alt), opx } 15 \% \text { ( } 8 \% \text { alt); ilm } 2 \% \text {; magn } 1 \% \text {; } \\
\text { traces of sulfides. }\end{array}$ \\
\hline Oxide-bearing gabbronorite & $\begin{array}{l}\mathrm{K} \\
\mu\end{array}$ & $\begin{array}{l}0.80 \\
0.44 \\
\text { Texture }\end{array}$ & $\begin{array}{c}0.82 \\
0.46 \\
\text { nedium }\end{array}$ & $\begin{array}{l}0.82 \\
0.46 \\
\text { ained or }\end{array}$ & $\begin{array}{l}0.83 \\
0.47 \\
\text { ic to su }\end{array}$ & $\begin{array}{l}0.83 \\
0.47 \\
\text { hitic, in }\end{array}$ & $\begin{array}{l}0.85 \\
0.48 \\
\text { stitial o }\end{array}$ & $\begin{array}{l}0.86 \\
0.48 \\
\text { es, patc }\end{array}$ & $\begin{array}{l}0.87 \\
0.49 \\
\text { s of sulfid }\end{array}$ & $\begin{array}{l}0.87 \\
0.50\end{array}$ & $\begin{array}{l}0.89 \\
0.49\end{array}$ & \\
\hline $\begin{array}{c}147-894 \mathrm{G}-17 \mathrm{R}-2(87-89) \\
\rho=2.96 \mathrm{~g} / \mathrm{cm}^{3}\end{array}$ & $\underset{\sigma}{\mathrm{Vp} / \mathrm{Vs}}$ & $\begin{array}{l}1.77 \\
0.22\end{array}$ & $\begin{array}{l}1.77 \\
0.22\end{array}$ & $\begin{array}{l}1.77 \\
0.21\end{array}$ & $\begin{array}{l}1.77 \\
0.21\end{array}$ & $\begin{array}{l}1.77 \\
0.21\end{array}$ & $\begin{array}{l}1.77 \\
0.21\end{array}$ & $\begin{array}{l}1.77 \\
0.21\end{array}$ & $\begin{array}{l}1.77 \\
0.21\end{array}$ & $\begin{array}{l}1.77 \\
0.21\end{array}$ & $\begin{array}{l}1.77 \\
0.21\end{array}$ & $\begin{array}{l}\text { Unit } 11 \text { Piece } 8 \\
\text { Plag } 60 \% \text { ( } 5 \% \text { alt); cpx } 25 \% \text { (10\% alt), opx } 15 \% \text { ( } 5 \% \text { alt); magn }<1 \% \text {, trace of } \\
\text { sulfides. }\end{array}$ \\
\hline Gabbronorite & $\begin{array}{l}\mathrm{K} \\
\mu\end{array}$ & $\begin{array}{l}0.77 \\
0.42 \\
\text { Texture }\end{array}$ & $\begin{array}{c}0.78 \\
0.43 \\
\text { nedium }\end{array}$ & $\begin{array}{c}0.79 \\
0.44 \\
\text { coarse }\end{array}$ & $\begin{array}{r}0.80 \\
0.45 \\
\text { ained, s }\end{array}$ & $\begin{array}{l}0.80 \\
0.45 \\
\text { edral gra }\end{array}$ & $\begin{array}{c}0.82 \\
0.46 \\
\text { lar to s }\end{array}$ & $\begin{array}{l}0.83 \\
0.46 \\
\text { phitic }\end{array}$ & $\begin{array}{l}0.83 \\
0.47\end{array}$ & $\begin{array}{l}0.84 \\
0.47\end{array}$ & $\begin{array}{l}0.84 \\
0.47\end{array}$ & \\
\hline $\begin{aligned} 147-894 \mathrm{G}-18 \mathrm{R}-1 & (130-132) \\
\rho & =3.01 \mathrm{~g} / \mathrm{cm}^{3} \\
\rho & =074 \%\end{aligned}$ & $\underset{\sigma}{\mathrm{Vp} / \mathrm{Vs}}$ & $\begin{array}{l}1.87 \\
0.25\end{array}$ & $\begin{array}{l}1.84 \\
0.24\end{array}$ & $\begin{array}{l}1.82 \\
0.23\end{array}$ & $\begin{array}{l}1.81 \\
0.23\end{array}$ & $\begin{array}{l}1.81 \\
0.23\end{array}$ & $\begin{array}{l}1.81 \\
0.23\end{array}$ & $\begin{array}{l}1.81 \\
0.23\end{array}$ & $\begin{array}{l}1.82 \\
0.23\end{array}$ & $\begin{array}{l}1.82 \\
0.23\end{array}$ & $\begin{array}{l}1.82 \\
0.23\end{array}$ & $\begin{array}{l}\text { Unit } 11 \text { Piece } 14 \mathrm{~A} \\
\text { Plag } 60 \% \text { ( } 5 \% \text { alt); cpx } 35 \% \text { (10\% alt). opx } 5 \% \text { (all alt); magn }<1 \% \text {, trace of } \\
\text { sulfides, both interstitial. }\end{array}$ \\
\hline $\begin{array}{l}\phi=0.74 \% \\
\text { Gabbronorite }\end{array}$ & $\begin{array}{l}\mathrm{K} \\
\mu\end{array}$ & $\begin{array}{l}0.81 \\
0.37 \\
\text { Texture }\end{array}$ & $\begin{array}{c}0.81 \\
0.40 \\
\text { ine- to }\end{array}$ & $\begin{aligned} 0.82 \\
0.41 \\
\text { dium-gr }\end{aligned}$ & $\begin{array}{r}0.82 \\
0.42 \\
\text { ed, sub }\end{array}$ & $\begin{array}{l}0.82 \\
0.43 \\
\text { ral grant }\end{array}$ & $\begin{array}{r}0.84 \\
0.43 \\
r \text { to sut }\end{array}$ & $\begin{array}{l}0.85 \\
0.44 \\
\text { itic }\end{array}$ & $\begin{array}{l}0.86 \\
0.44\end{array}$ & $\begin{array}{l}0.87 \\
0.44\end{array}$ & $\begin{array}{l}0.88 \\
0.44\end{array}$ & \\
\hline $\begin{aligned} 147-894 \mathrm{G}-19 \mathrm{R}-1 & (37-39) \\
\rho & =2.86 \mathrm{~g} / \mathrm{cm}^{3}\end{aligned}$ & $\underset{\sigma}{\mathrm{Vp} / \mathrm{Vs}}$ & $\begin{array}{l}2.23 \\
0.33\end{array}$ & $\begin{array}{l}2.13 \\
0.31\end{array}$ & $\begin{array}{l}2.08 \\
0.30\end{array}$ & $\begin{array}{l}2.05 \\
0.30\end{array}$ & $\begin{array}{l}2.03 \\
0.29\end{array}$ & $\begin{array}{l}2.02 \\
0.29\end{array}$ & $\begin{array}{l}2.03 \\
0.29\end{array}$ & $\begin{array}{l}2.04 \\
0.30\end{array}$ & $\begin{array}{l}2.05 \\
0.30\end{array}$ & $\begin{array}{l}2.06 \\
0.30\end{array}$ & $\begin{array}{l}\text { Unit } 11 \text { Piece } 7 \\
\text { Plag } 60 \% \text { (10\% alt to clay); cpx } 25 \% \text { ( } 20 \% \text { alt), opx } 15 \% \text { ( } 10 \% \text { alt), both alt to } \\
\text { amph; magn }<1 \% \text {, sulfide tr. }\end{array}$ \\
\hline Gabbronorite & $\mu$ & $\begin{array}{l}0.21 \\
\text { Texture }\end{array}$ & $\begin{array}{l}0.24 \\
\text { ine- to }\end{array}$ & $\begin{array}{l}0.26 \\
\text { dium-gr }\end{array}$ & $\begin{array}{l}0.27 \\
\text { ed, sub }\end{array}$ & $\begin{array}{l}0.27 \\
\text { Iral grant }\end{array}$ & $\begin{array}{l}0.29 \\
\text { in to sut }\end{array}$ & $\begin{array}{l}0.29 \\
\text { iitic, his }\end{array}$ & $\begin{array}{l}0.29 \\
y \text { alt, mas }\end{array}$ & $\begin{array}{l}0.29 \\
\text { natic fat }\end{array}$ & $\begin{array}{l}0.29 \\
\text { c, plag or }\end{array}$ & entation \\
\hline $\begin{aligned} 147-894 \mathrm{G}-20 \mathrm{R}-2 & (33-35) \\
\rho & =2.97 \mathrm{~g} / \mathrm{cm}^{3}\end{aligned}$ & $\underset{\sigma}{\mathrm{Vp} / \mathrm{Vs}}$ & $\begin{array}{l}1.94 \\
0.27\end{array}$ & $\begin{array}{l}1.86 \\
0.25\end{array}$ & $\begin{array}{l}1.83 \\
0.24\end{array}$ & $\begin{array}{l}1.82 \\
0.23\end{array}$ & $\begin{array}{l}1,82 \\
0.23\end{array}$ & $\begin{array}{l}1.83 \\
0.24\end{array}$ & $\begin{array}{l}1.84 \\
0.24\end{array}$ & $\begin{array}{l}1.84 \\
0.24\end{array}$ & $\begin{array}{l}1.85 \\
0.24\end{array}$ & $\begin{array}{l}1.85 \\
0.24\end{array}$ & $\begin{array}{l}\text { Unit } 13 \text { Piece } 4 \\
\text { Plag } 53 \% \text { ( } 5 \% \text { alt); cpx } 35 \% \text { ( } 20 \% \text { alt), opx } 10 \% \text { ( } 7 \% \text { alt); magn } 2 \% \text {; ilm } 1 \% \text {; } \\
\text { pyrite and chalcopyrite trace. }\end{array}$ \\
\hline $\begin{array}{l}\phi=0.53 \% \\
\text { Gabbronorite }\end{array}$ & $\begin{array}{l}\mathrm{K} \\
\mu\end{array}$ & $\begin{array}{l}0.84 \\
0.35 \\
\text { Texture }\end{array}$ & $\begin{array}{c}0.82 \\
0.39 \\
\text { nedium }\end{array}$ & $\begin{array}{l}0.81 \\
0.40 \\
\text { ained, } \mathrm{h}\end{array}$ & $\begin{array}{l}0.82 \\
0.41 \\
\text { idiomor }\end{array}$ & $\begin{array}{l}0.82 \\
0.42 \\
\text { ic granul }\end{array}$ & $\begin{array}{l}0.85 \\
0.42\end{array}$ & $\begin{array}{l}0.86 \\
0.42\end{array}$ & $\begin{array}{l}0.87 \\
0.42\end{array}$ & $\begin{array}{l}0.88 \\
0.42\end{array}$ & $\begin{array}{l}0.89 \\
0.42\end{array}$ & \\
\hline $\begin{array}{l}147-895 \mathrm{~B}-1 \mathrm{R}-1(127-129) \\
\rho=2.70 \mathrm{~g} / \mathrm{cm}^{3} \\
\phi=2.19 \% \\
\text { Harzburgite }\end{array}$ & $\begin{array}{c}\mathrm{Vp} / \mathrm{Vs} \\
\sigma \\
\mathrm{K} \\
\mu\end{array}$ & $\begin{array}{l}1.88 \\
0.25 \\
0.39 \\
0.18\end{array}$ & $\begin{array}{l}1.87 \\
0.25 \\
0.41 \\
0.19\end{array}$ & $\begin{array}{l}1.88 \\
0.25 \\
0.43 \\
0.20\end{array}$ & $\begin{array}{l}1.88 \\
0.25 \\
0.44 \\
0.20\end{array}$ & $\begin{array}{l}1.89 \\
0.26 \\
0.45 \\
0.20\end{array}$ & $\begin{array}{l}1.93 \\
0.27 \\
0.49 \\
0.21\end{array}$ & $\begin{array}{l}1.96 \\
0.27 \\
0.52 \\
0.21\end{array}$ & $\begin{array}{l}1.97 \\
0.28 \\
0.54 \\
0.21\end{array}$ & $\begin{array}{l}1.99 \\
0.28 \\
0.56 \\
0.21\end{array}$ & $\begin{array}{l}2.00 \\
0.29 \\
0.57 \\
0.21\end{array}$ & $\begin{array}{l}\text { Unit } 3 \text { Piece } 17 \\
\text { Ol } 85 \% \text { (50\% alt) replaced by serp and magn; opx } 15 \% \text { ( } 5 \% \text { alt); spinel }<1 \% \text {. }\end{array}$ \\
\hline
\end{tabular}


Table 3 (continued).

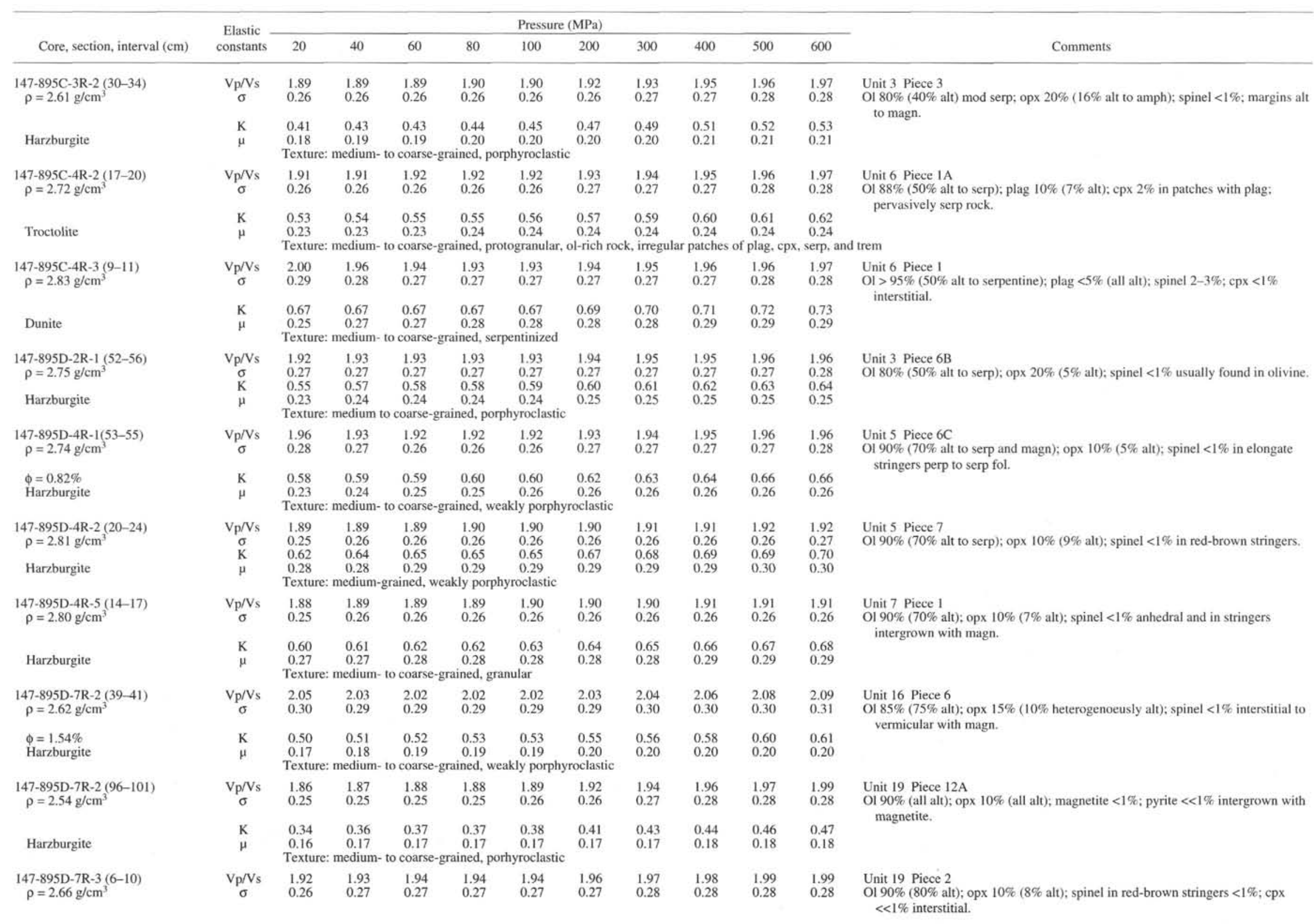


Table 3 (continued).

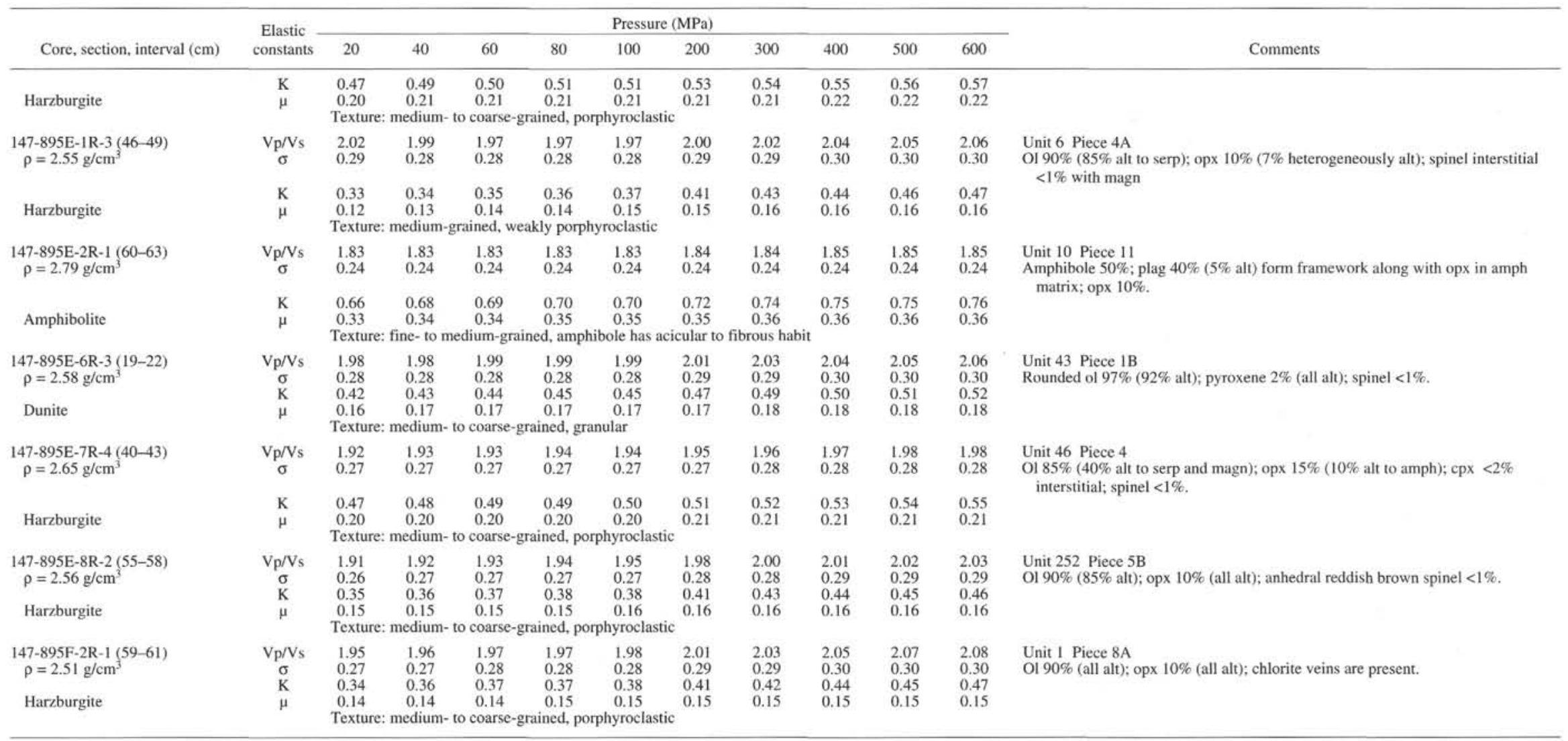

Notes: alt $=$ altered, fol $=$ foliation, mod $=$ moderately, perp $=$ perpendicular, $\min =$ minerals, ol $=$ olivine, $\mathrm{cpx}=$ clinopyroxene, opx $=$ orthopyroxene, plag $=$ plagioclase, amph $=$ amphibole, trem $=$ tremolite, magn $=$ magnetite, serp $=$ ser pentine, ilm = ilmenite, pyr = pyrite. Mineral modes from point counts. 
A

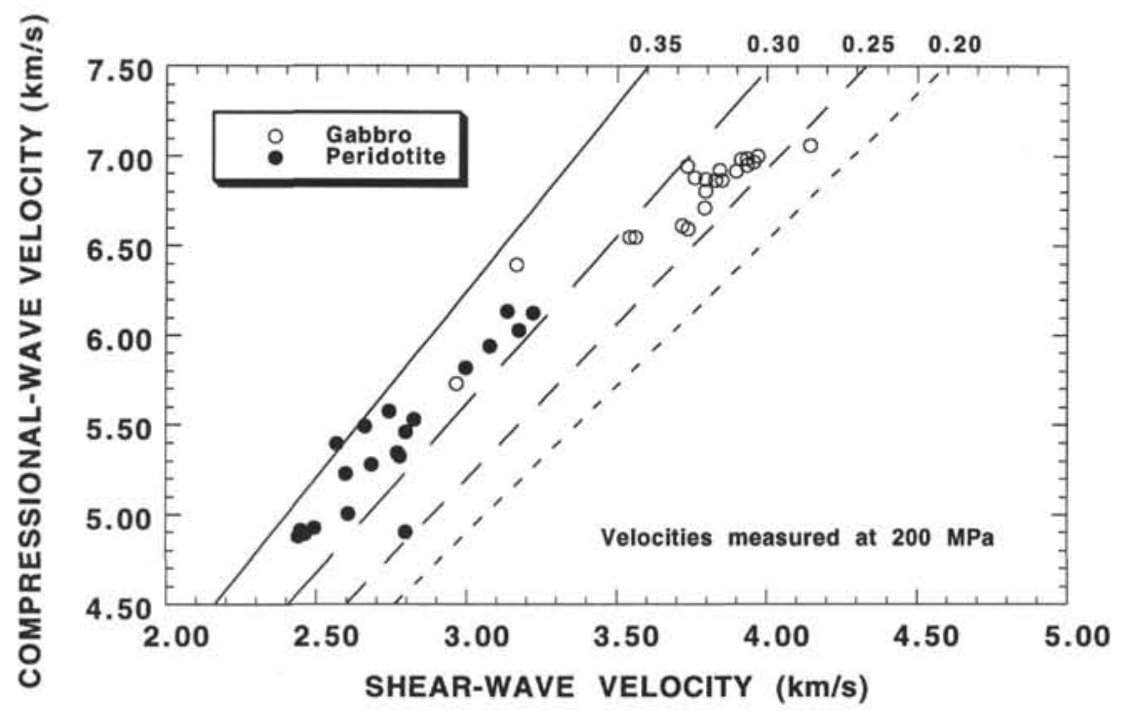

B

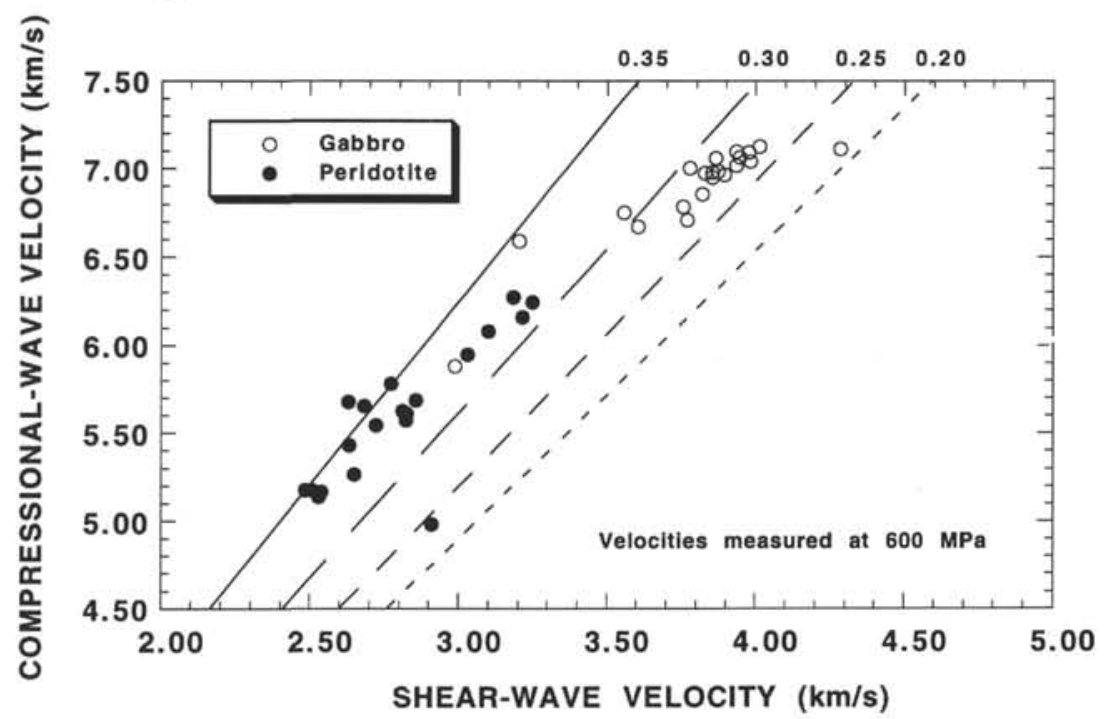

Figure 15. Compressional- and shear-wave velocity plot for the Hess Deep gabbro and serpentinized peridotite samples. Lines of constant Poisson's ratio are also plotted and the effects of changes in pressure from $200 \mathrm{MPa}$ (A) to $600 \mathrm{MPa}$ (B) are examined. 